DOI: 10.14807/ijmp.v11i9.1399

\title{
ENERGY SECTOR IMPACT ON COUNTRY'S ECONOMIC SECURITY: BALTIC SEA REGION EU COUNTRIES' CASE
}

\author{
Rima Zitkiene \\ Mykolas Romeris University, Lithuania \\ E-mail: rizit3@mruni.eu \\ Jurij Matyskevic \\ DXC Technology, Lithuania \\ E-mail: mediajurijlt@gmail.com \\ Inna Kremer-Matyskevic \\ Mykolas Romeris University, Lithuania \\ E-mail: inna_kremer@hotmail.com \\ Nataliia Korzhenivska \\ State Agrarian and Engineering University in Podilya, Ukraine \\ E-mail: nkorzhenivska@gmail.com \\ Svitlana Zaika \\ Kharkiv Petro Vasylenko National Technical University of Agriculture, Ukraine \\ E-mail: zaika.svitlana175@gmail.com \\ Submission: $8 / 2 / 2020$ \\ Revision: 8/9/2020 \\ Accept: 8/26/2020
}

\section{ABSTRACT}

The article object is to is a relatively new research direction in economic theory - economic security at the macro-level. One of the aims of this article is to reveal the country's economic security idea and to choose methods for this economic phenomenon evaluation as well as to suggest the method to evaluate the energy sector's impact on this economic phenomenon. Firstly, the authors review different approaches to economic security principles and do some assumptions related to the country's economic security concept. There is shortly described the energy sector. Since the scientific problem is how to evaluate the energy sector and the country's security and what impact the energy sector has on the country's economic security, the authors have selected methods to analyze the links between energy sector activities and economic security. Furthermore, there were presented the results of regression analyzes and concluded what energy sector indicators influence countries' economic security. 
DOI: 10.14807/ijmp.v11i9.1399

Keywords: Energy sector; Economic security; External threats; Internal threats; Management

\section{INTRODUCTION}

The phenomenon of the country's economic security is a relatively new research direction in economic theory, but at the same time, it is an unquestionably integral component of national security which paradigm, as well as a new approach to the perception of national economic security, was formed by economist Keynes in the 1930s. From his point of view, the main threats to the national economy are not competition for foreign goods but unemployment and economic depression (ZUZEVICIUTE et al., 2018). In Western countries, economic security is usually studied at the micro-level, mostly there is an examination of the financial stability of a household or individual. Less research is done at the macro level by analyzing economic security through national security threats identification. One of the aims of this article is to reveal the country's economic security idea and to choose methods for this economic phenomenon evaluation.

\section{LITERATURE REVIEW}

\subsection{Energy sector and economic security in international context}

In the economic globalization conditions, revealing the essence of economic security and identifying its real threats as well as providing reliable and effective problem-solving methods is a pretty important task. Therefore, solving economic security problems becomes a multifaceted task, which must include not only a security function but also a comprehensive approach, taking into account the overall country's political and financial capabilities.

Economic security structure has been presented by Tamosiuniene and Munteanu (2015) in their theoretical research. According to the offered scheme economic security should be divided into two approaches: individual and macroeconomic (see Figure 1).

Whereas the individual approach describes the economic security as an individual subject stable income and other sources that maintain the living standard in the present and the near future, i.e.: permanent solvency, predictable cash flow, efficient use of human capital.

The macroeconomic security approach is related to a sophisticated history because of the period of this method rising matches with the times of the two World Wars. Especially, the formation of this attitude to economic security was supported by a Russian economic school, which using critical meanings, attempted to quantify economic security, as well as a model 
DOI: 10.14807/ijmp.v11i9.1399

developed by Professor Lino Briguglio, that defined economic security as the state's economic vulnerability and resistance level.

Figure 1: Economic security structure

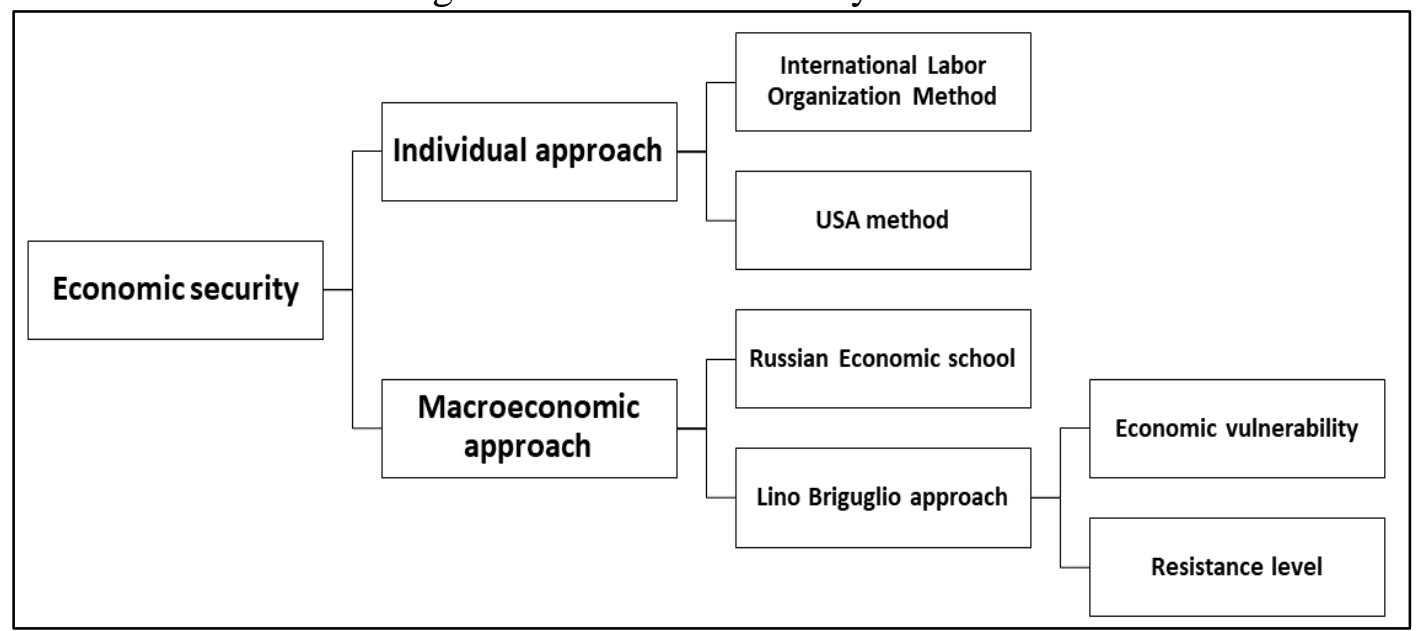

Source: Tamosiuniene, Munteanu (2015)

Since the object of this research is the country's economic security, let's review some insights into the macroeconomic approach.

Scientists from different countries have already begun to analyze the principles of economic security, but this area is still not fully formed on a theoretical basis likewise evaluation methodology of this phenomenon does not have the general pattern.

In accordance with Simanavicius et al. (2019) research, the European Union (EU) has two standpoints related to the concept of economic security. The first point is connected to the EU position in the global economic system. There are collected various information on the economic objectives of the European Union, economic security concept interpretation, that are presented on the EU official portal.

The European Union highlights the importance of European integration into the globalization process of a competitive economy. The second point is related to the largest official organization dealing with security complex issues in Europe - the Organization for Security and Co-operation in Europe (OSCE), which develops measures to reduce military confrontation and increase security in Europe. The OSCE security concept contains several components: political and military dimension, economic dimension, and human rights issues.

How to newly describe the economic security purpose, and to what scope are nowadays applied quantitative evaluation methods correct has been researched by Giriuniene et al. (2019). They argue it is worth considering that the state's economic security cannot be separated from other factors of the state's security. They state, that there is no basis to assert 
DOI: 10.14807/ijmp.v11i9.1399

that a state, that territorial integrity and, meantime, security is facing actual external threats, with which a state cannot cope efficiently, can be considered economically secure because the conquerors can make use of the state’s economic resources.

Economic security understood as the elimination the internal threats by Johnstone (2013), Hipp (2016), Angulo-Guerrero (2017). On the contrary, economic security has been showed from the prism of external threats, suchlike countries' dependency on energy resources, poverty, unemployment, migration, and corruption by Popescu (2014) and Franki (2015).

Few insights to this phenomenon as output of modern economic security categories analysis has been made by Svetlakov and Glotina (2018):

- economic security became the spot to the countries and a significant element of nationality;

- economic security concept is a rather complex and controversy category;

- without economic security providing, a country risks not solve the problem that faces both internally and internationally;

- while estimating the economic security of a country, it is necessary to establish certain conditions that set out the main assumptions for dealing the category of economic security: differences in national interests, restricted public resources, increased goods and production competition, increased individual countries competitiveness, others take into account as a real threat to national interests of the country;

- state's economic security is a complex socio-economic concept that images changing material production conditions as well as external and internal threats to the country's economy.

Possible general country's economic security concept, that can be divided into four general fields has been offered by Kremer-Matyskevic and Cernius (2019) in their previous research:

1) Economic development;

2) Living standard;

3) Internal threats;

4) External threats.

The fifth part of the country's economic security concept which was presented by Kremer-Matyskevic and Cernius (2019) is the principles or foundation of economic security. 
DOI: 10.14807/ijmp.v11i9.1399

Country risk in the context of economic security and sustainability has been measured by Sviderskè (2015). According to this researcher, every government in each country wants to be economically preserved from any dangers. Economic instruments have long been a component of the government's strategy, meaning that these measures have an influence on other countries and their policies. From a traditional point of view, economic security is safety against other authorities and the manipulation of other powers.

Referring to Rehm et al. (2012), Mendoza (2019), Stanaway et al. (2017) some knowledge about economic security concept are presented below:

- economic security is the main subject in national security, which is one of the resources to ensure a balance between national security;

- economic security is one of the national, regional and global security factors that aim to economically secure and preserve every individual, community or national economy;

- the fundamental objective of governments, regional and international organizations is to warrant universal human security;

- the state's economic conditions are considered as a source and basis for tackling poverty, hunger, social and economic inequalities.

Economic security risk has been treated from the shadow economy side by Burak and Simanaviciene (2018). Authors have developed recommendations for minimizing and preventions risk and threats to the state's economic security:

- create an effective mechanism for interaction and exchange of information on the issues of counteraction to the laundering of illegally received money, which allows you to make inquiries and receive the necessary information as soon as possible;

- to improve the system of counteracting money laundering and terrorism financing, expanding the list of subjects of financial monitoring, as well as establishing a single information channel between the relevant state institution.

Economic security has been stated as a key component of the national security system, which is characterized by the ability of the state's national economy and its regions to ensure stable continuous development and relative protection for both individual and the whole country, in reliance on economic methods by Kromalcas et al. (2019). 
DOI: 10.14807/ijmp.v11i9.1399

Based on Dadalko et al. (2017), Kremer-Matyskevic and Cernius (2019) shown collected definitions by the different approaches in Table 1.

Table 1: Definitions of economic security

\begin{tabular}{|c|c|c|}
\hline Approach & Description & References \\
\hline \multirow[t]{4}{*}{$\begin{array}{l}\text { By content and } \\
\text { concept }\end{array}$} & $\begin{array}{l}\text { protection individual vital interests, society, the countries } \\
\text { and national economic interests }\end{array}$ & \multirow{11}{*}{ Dadalko et al. (2017) } \\
\hline & state of economy, authorities, economic system & \\
\hline & economic functioning regime & \\
\hline & qualitative characteristics of the economic system & \\
\hline \multirow{3}{*}{ By subject } & vital interests & \\
\hline & national interests & \\
\hline & economic interests & \\
\hline \multirow{2}{*}{$\begin{array}{l}\text { By security } \\
\text { mechanism } \\
\text { assurance }\end{array}$} & without mechanism indication & \\
\hline & $\begin{array}{l}\text { normative - legal, administrative - organizational, economic, } \\
\text { technological, informational, etc. }\end{array}$ & \\
\hline \multirow{2}{*}{$\begin{array}{l}\text { By depending on } \\
\text { the } \\
\text { consequences }\end{array}$} & dangers and threats & \\
\hline & unfavourable external and internal factors & \\
\hline
\end{tabular}

Generalizing all authors' minds - economic security is national security goal that idea is to protect the state from external and internal threats and the same time to maintain the state's economic development

\subsection{Energy sector and economic security in European context}

Although in the recent period, the Energy sector in Europa Union countries is constantly transforming from traditional to climate-neutral, this economic sector still will play the main role in economic development. After analyzing the European Commission and 8 countries belonging to the Baltic sea region approaches to the energy sector, the authors of the article breakdown energy sector activities into main points and showed it in Figure 2.

The energy sector divides into 5 fields: natural gas, oil and oil products, electricity, and heat sector (heat economy). Since economics science seldom defines fields of the energy sector, it was decided to take as the main definition from the official portals of different energy institutions: 
Figure 2: Energy sector

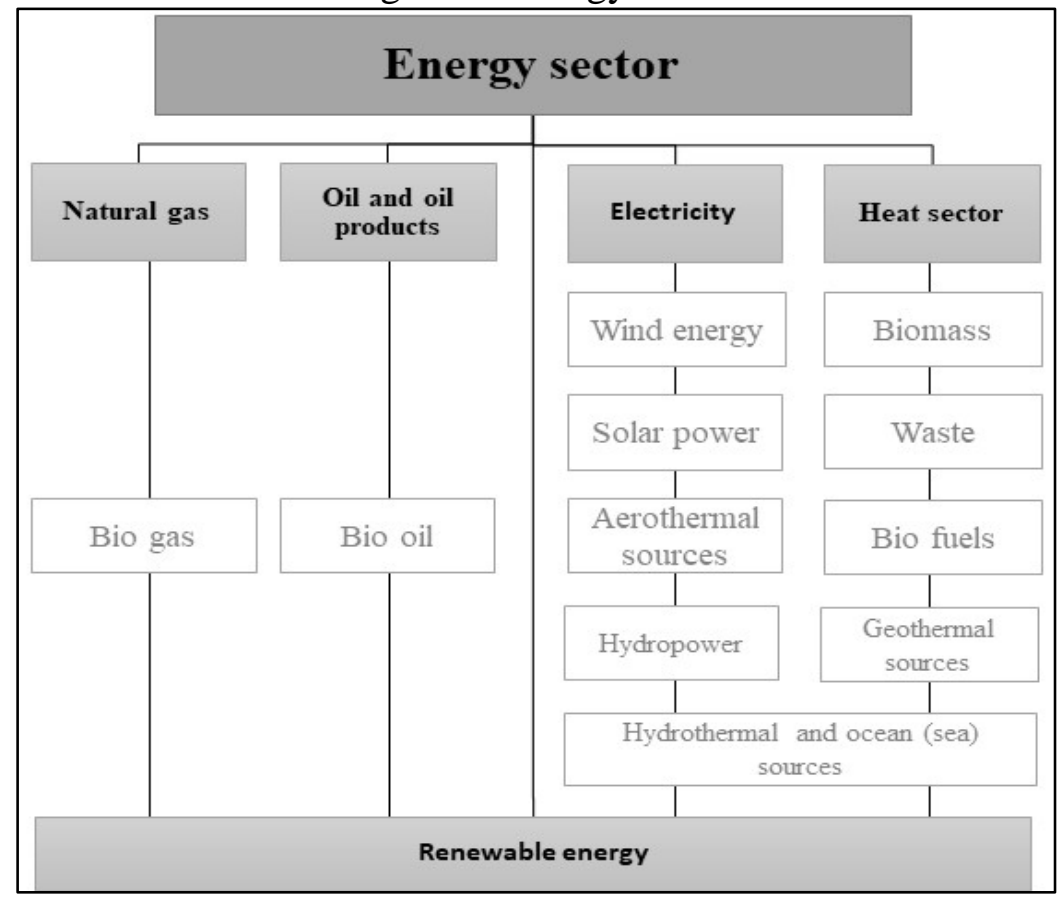

Source: composed by authors

- according to the American Petroleum Institute (2020) natural gas is made up of a mixture of four naturally occurring gases, all of which have different molecular structures. This mixture consists primarily of methane, ethane, butane, and propane. Natural gas has been considered by Melton et al. (2015) to be the third-most widely used energy source in the world, accounting for approximately 21 percent of total primary energy demand;

- explained oil and oil products as the mixtures of hydrocarbons that formed from the remains of animals and plants (diatoms) that lived millions of years ago in a marine environment before the existence of dinosaurs. Over millions of years, the remains of these animals and plants were covered by layers of sand, silt, and rock. Heat and pressure from these layers turned the remains into what we now call crude oil or petroleum. The word petroleum means rock oil or oil from the earth.

- the same organization - U.S. Energy Information Administration (2020) presents explanation about electricity - is the flow of electrical power or charge. Electricity is both a basic part of nature and one of the most widely used forms of energy. The electricity that all use is a secondary energy source because it is produced by converting primary sources of energy such as coal, natural gas, nuclear energy, solar energy, and wind energy, into electrical power. Electricity is also referred to as an energy carrier, which means it can be converted to other forms of energy such as mechanical energy 
DOI: 10.14807/ijmp.v11i9.1399

or heat. Primary energy sources are renewable or nonrenewable energy, but the electricity we use is neither renewable nor nonrenewable;

- heating (heat) sector is a field of energy economy directly related to heating and hot water generation, transmission, supply and consumption - this explanation is provided by Ministry of Energy of the Republic of Lithuania on its official portal (MINISTRY OF ENERGY OF THE REPUBLIC OF LITHUANIA, 2020). The strategic goal in the heating sector is consistent and balanced renovation (optimisation) of the centralised district heating supply systems, which ensures effective heating consumption, reliable, economically-attractive (competitive) supply and generation, provides a possibility for installation of state-of-the-art and green technologies, using local and renewable energy resources, ensures flexibility of the system and favorable investment climate;

- renewable energy is energy from sources that are naturally replenishing but flowlimited; renewable resources are virtually inexhaustible in duration but limited in the amount of energy that is available per unit of time (MINISTRY OF ENERGY OF THE REPUBLIC OF LITHUANIA, 2020).

According to Bhatt and Tao (2020) research efforts on utilizing environmentally friendly renewable alternative sources have gained weighty interest, because of the limited supply of conventional fossil raw materials. As it may be seen from Figure 2, traditional energy has its varieties as renewable energy: natural gas - bio gas; oil products - bio oil; electricity wind energy, solar power, aerothermal sources, hydropower, hydrothermal and ocean (sea) sources; heat sector - biomass, waste, bio fuels, geothermal sources, and hydrothermal and ocean (sea) sources.

The research between links of the country's economic security and various economic sectors' is especially rare. Although energy is one of the most important components of a country's economy, the impact of this sector on economic security is a rather complex task due to the different methods of analysis and the approach of scientists.

\section{METHODOLOGY}

\subsection{Measures to evaluate energy sector activity}

Since the scientific problem is how to evaluate the energy sector and the country's security and what impact the energy sector has on the country's economic security, firstly it needs to select what indicators we have to use to evaluate energy sector activities. Most of the various 
INDEPENDENT JOURNAL OF MANAGEMENT \& PRODUCTION (IJM\&P)

http://www.ijmp.jor.br

v. 11, n. 9, Special Edition (Baltic States), November 2020

ISSN: 2236-269X

DOI: 10.14807/ijmp.v11i9.1399

scientists use energy balance indicators are presented in Table 2. The energy balance describes all the physical flows of energy that are embodied in energy products.

Table 2: Energy balance indicators' description

\begin{tabular}{|c|c|c|}
\hline Indicator & Indicator description & $\begin{array}{c}\text { Source to } \\
\text { analyse }\end{array}$ \\
\hline Production & $\begin{array}{l}\text { Comprises the production of primary energy, i.e. hard coal, lignite, peat, } \\
\text { crude oil, NGLs, natural gas, biofuels and waste, nuclear, hydro, } \\
\text { geothermal, solar and the heat from heat pumps that is extracted from the } \\
\text { ambient environment. Production is calculated after removal of impurities } \\
\text { (e.g. sulphur from natural gas). }\end{array}$ & \\
\hline Imports & $\begin{array}{l}\text { Comprise amounts having crossed the national territorial boundaries of the } \\
\text { country whether or not customs clearance has taken place. }\end{array}$ & \\
\hline Exports & $\begin{array}{l}\text { Comprise amounts having crossed the national territorial boundaries of the } \\
\text { country whether or not customs clearance has taken place. }\end{array}$ & \\
\hline $\begin{array}{l}\text { Total primary } \\
\text { energy supply }\end{array}$ & $\begin{array}{l}\text { Total primary energy supply (TPES) is made up of production + imports - } \\
\text { exports - international marine bunkers - international aviation bunkers } \pm \\
\text { stock changes. Note, exports, bunkers and stock changes incorporate the } \\
\text { algebraic sign directly in the number. }\end{array}$ & \\
\hline $\begin{array}{l}\text { Total final } \\
\text { consumption }\end{array}$ & $\begin{array}{l}\text { Equal to the sum of the consumption in the end-use sectors. Energy used } \\
\text { for transformation processes and for own use of the energy producing } \\
\text { industries is excluded. Final consumption reflects for the most part } \\
\text { deliveries to consumers (see note on stock changes). }\end{array}$ & \\
\hline $\begin{array}{l}\text { Electricity, CHP } \\
\text { and heat plants }\end{array}$ & $\begin{array}{l}\text { Sum of Electricity plants, CHP plants and heat plants. } \\
\text { plant. Main activity producers generate electricity for sale to third parties, } \\
\text { as their primary activity. }\end{array}$ & $\begin{array}{l}\text { IEA } \\
\text { (2019), } \\
\text { World } \\
\text { Energy }\end{array}$ \\
\hline $\begin{array}{l}\text { Oil refineries, } \\
\text { transformation }\end{array}$ & $\begin{array}{l}\text { Positive figures under 'Oil Products' refer to the manufacture of finished oil } \\
\text { products. Negative figures for 'Crude, NGL and feedstocks' refer to the } \\
\text { refinery inputs. }\end{array}$ & $\begin{array}{l}\text { Balances } \\
\text { (database) }\end{array}$ \\
\hline Transport & $\begin{array}{l}\text { Consumption in transport covers all transport activity (in mobile engines) } \\
\text { regardless of the economic sector to which it is contributing. }\end{array}$ & \\
\hline Residential & $\begin{array}{l}\text { Includes consumption by households, excluding fuels used for transport. } \\
\text { Includes households with employed persons. }\end{array}$ & \\
\hline $\begin{array}{l}\text { Commercial and } \\
\text { public services }\end{array}$ & Consumption by commercial and public services & \\
\hline $\begin{array}{l}\text { Other final } \\
\text { consumption }\end{array}$ & $\begin{array}{l}\text { Includes agriculture/forestry, fishing, non-specified (other) and non-energy } \\
\text { use. }\end{array}$ & \\
\hline $\begin{array}{l}\text { Electricity } \\
\text { output }\end{array}$ & $\begin{array}{l}\text { Shows the total number of GWh generated by power plants. Contrary to } \\
\text { the Energy Statistics, electricity production for hydro pumped storage is } \\
\text { excluded within the Energy Balances. }\end{array}$ & \\
\hline $\begin{array}{l}\mathrm{Total}_{\mathrm{CO}} \\
\text { emissions - Fuel } \\
\text { Combustion (Mt } \\
\text { of } \mathrm{CO}_{2} \text { ) }\end{array}$ & $\begin{array}{l}\text { Total CO2 emissions - Fuel Combustion (Mt of CO2) presents total CO2 } \\
\text { emissions from fuel combustion. This includes CO2 emissions from fuel } \\
\text { combustion reported in IPCC Source/Sink Category } 1 \text { A Fuel Combustion } \\
\text { Activities and those which may be reallocated to IPCC Source/Sink } \\
\text { Category } 2 \text { Industrial Processes and Product Use under the } 2006 \text { IPCC } \\
\text { Guidelines. }\end{array}$ & \\
\hline
\end{tabular}

Source: composed by authors

Nowadays, in the energy policy change from traditional to climate neutral, researchers have mostly used an emission indicator to assess the performance of the energy sector.

However, the authors of this article would like to provide several examples, how the energy is examined: 
DOI: 10.14807/ijmp.v11i9.1399

- Chu et al. (2020) in their research used the carbon price volatility to the risk management of the $\mathrm{CO} 2$ emissions trading market;

- Figaj et al. (2020) proposed a hybrid geothermal-solar-wind system that was modelled and simulated by adopted software. Researchers' designed system is managing adequately the thermal energy flows in order to match the thermal energy demand of the user;

- in Arumägi and Kalamees (2020) analysis detailed energy performance-related costs of the actual solution components compared with the current practice are included, as well as the costs due to operational energy use and renewable energy harvesting are calculated;

- Masip Macía et al. (2019) stated, that the mining industry is characterized by high consumption of energy due to the wide diversity of processes involved, specifically the transportation of ore slurry via pipeline systems;

- An energy usage indicator was used to establish a metric to rank the buildings of each typology according to their energy efficiency in Bernardo and Oliveira (2018) article.

Though one of the authors of this research has already analyzed the impact of the energy sector on Lithuania's gross domestic product and suggested to use economic indicators of the energy sector such as energy sector price change (percent), energy sector value-added, the amount of energy sector taxes paid to the budget, the net profitability of the energy sector (MACERINSKIENE; KREMER-MATYSKEVIC, 2017), in this research to evaluate energy sector impact to state's economic security, it was suggested to use energy balance indicators (excluding CO2 emissions) downloaded from World Energy Balances database (INTERNATIONAL ENERGY AGENCY, 2020).

\subsection{Measures to evaluate country's economic security}

Given that the representatives of Western countries' economic Science studying economic security at the macro level use a model developed by professor Briguglio (2015) that reflects economic security, with respect to the vulnerability of the country's economy and its capacity, as well as the level of resistance (to combat the crisis and to prepare for shock absorption), it was decided to use indicators that may describe this method by a better way.

Economic vulnerability is assessed by the degree of economic openness, which makes it particularly sensitive to the economic conditions of other countries; dependence on import restrictions; isolation, that leads to high transport costs and distance from the major sale sites, Morkunas et al. (2018). As a measures to assess economic vulnerability such indicators like. 
DOI: 10.14807/ijmp.v11i9.1399

According to Zavadskas et al. (2018) the resilience of the economy is assessed as crisis preparedness: inflation and unemployment rates, government balance, external debt, government spending, and shock absorption level: market efficiency, government efficiency, social and human development, sustainability.

Figure 3 presents indicators were chosen to measure economic security based on twolevel: economic vulnerability and the resilience of the economy.

Figure 3: Economic security indicators

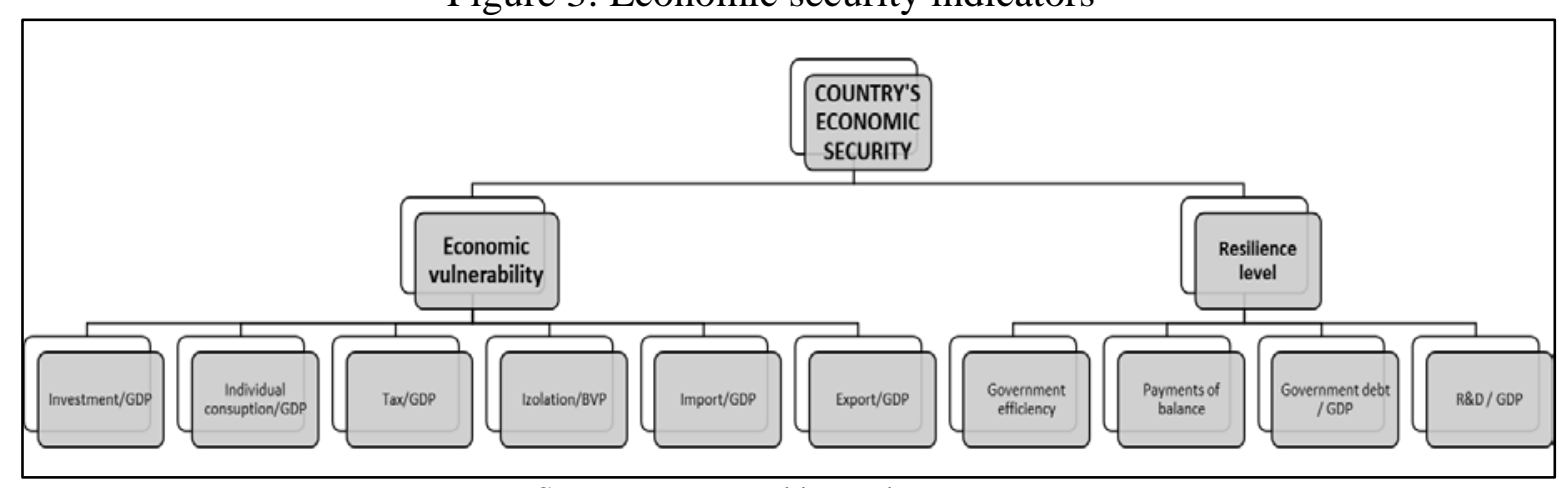

Source: composed by authors

Reflected the plenty range of scientist research of economic vulnerability authors have made the decision to select the following indicators:

- Investment/GDP - Lapinskaite et al. (2020) believe this rate shows the state's sustainable economic development;

- Individual consumption/GDP - according to Dagiliute (2008) sustainable production and consumption are one of the main goals for countries economic development;

- Tax/GDP - Tax analysis shows the effects of tax policy changes on different groups of individuals via the effects on prices and returns to labor and capital (AUERBACH, 2018));

- Isolation/GDP - the developed logistic system also may predict the state's economic development and globalization and integration level in the global economy;

- Export/GDP and Import/GDP rate could describe how much the state's economy is globalized and not dependent on other countries' economies. Government consolidated gross debt.

By authors of this article opinion resilience level can be described by following coefficients:

- Government efficiency - traditionally this indicator can be shown by Total general government expenditure/GDP rate; 
- Balance of payments - from theoretical background - the balance of payments, also known as balance of international payments, summarizes all transactions that a country's individuals, companies, and government bodies complete with individuals, companies, and government bodies outside the country;

- Government consolidated gross debt - as Eurostat (EUROPEAN COMMISSION, 2020) explains government debt is defined as total gross debt at nominal value outstanding at the end of the year and consolidated between and within the sectors of general government;

- $\quad$ R\&D - as Galindo-Rueda at el. (2018) state investment in research and development is a key driver of innovation and economic growth.

Thus, the above written indicators from 2.1. and 2.2. section downloaded from World Energy Balance database (INTERNATIONAL ENERGY AGENCY, 2020) and Eurostat database (EUROPEAN COMMISION, 2020), authors use to evaluate energy sector activities' impact on Baltic sea region EU countries' economic security.

For getting the result there were done a few steps:

1) To describe the Baltic sea region in EU context;

2) To download the data from databases;

3) To define the period during which the analysis will be performed;

4) To prepare the data for correlation and regression analysis using SPSS software package;

5) To present the results of the analysis.

\section{RESULTS}

First of all, it needs to describe what is Baltic sea region EU countries (EUSBSR). Figure 4 shows the map which presents thus countries.

Accordance to official portal of Baltic sea region strategy the EU member states involved in the EUSBSR are Sweden, Denmark, Estonia, Finland, Germany, Latvia, Lithuania and Poland. 
DOI: 10.14807/ijmp.v11i9.1399

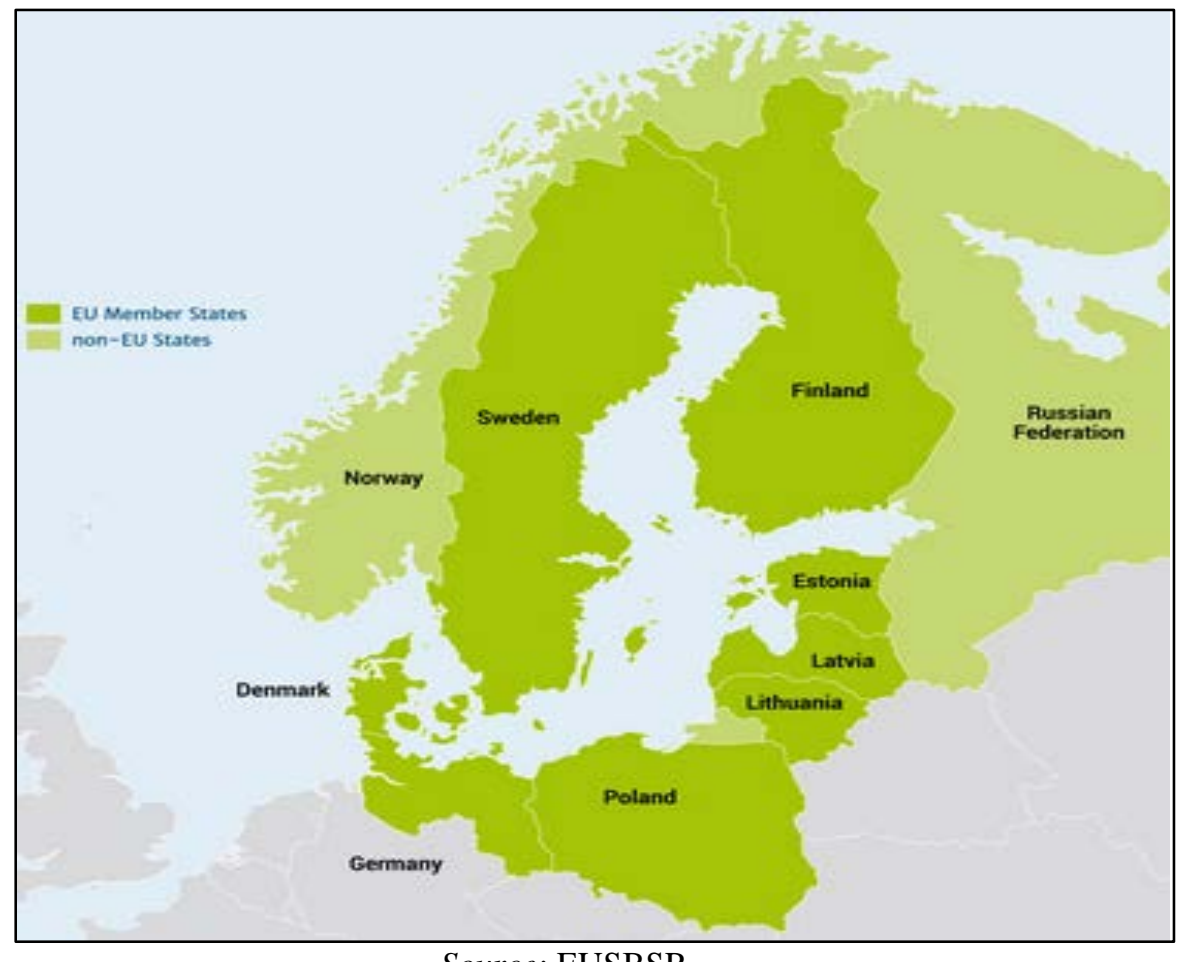

Source: EUSBSR

Following second step described in 2 section for getting the results of research there were downloaded energy data (13 indicators) from World Energy Balances database (INTERNATIONAL ENERGY AGENCY, 2020). This database lets to analyze data set from 1971 to 2018 years. Data from ten indicators measuring the country's economic security took from European commission official statistics portal - Eurostat (EUROPEAN COMMISION, 2020). The economic security dataset lets to assess only the 2008-2018 period.

In this article, the authors evaluate the 2008-2018 years period. There also were prepared data for correlation and regression analyses by coding all indicators:

Energy sector indicators are independent (X):

- ENProd- Production;

- ENImp - Imports;

- ENExp - Exports;

- ENSup - Total primary energy supply;

- ENTips - Electricity, CHP and heat plants;

- ENOil - Oil refineries, transformation;

- ENCon - Total final consumption; 
DOI: 10.14807/ijmp.v11i9.1399

- $\quad$ ENInd - Industry;

- $\quad$ ENTr - Transport;

- $\quad$ ENRes - Residential;

- ENServ - Commercial and public services;

- ENOther - Other final consumption;

- ENOut - Electricity output

Country’s economic security indicators are dependent (Y):

- ESGd - Government consolidated gross debt;

- $\quad$ ESIc - Actual individual consumption;

- ESExp - Export;

- ESImp - Import;

- ESLog - Isolation;

- $\quad$ ESBp - Balance of payments;

- $\quad$ ESRd - R\&D;

- ESTax - Tax on GDP;

- ESInv - Investment;

- ESGex - Total general government expenditure

Further the result of research is are presented.

First of all, the authors are preparing data of each country for correlation analysis in the SPSS software package. After revealing the significant links between the Energy sector and Economic security indicators which values are more than 0,7 or less $-0,7$, this article researcher prepare regression analysis. Firstly, we take into account R square values that show how much percent of data is included in the analysis, second step to check P-value, that shows the significance of links between dependent and independent variables. P-value has to be less than 0.05 . 
INDEPENDENT JOURNAL OF MANAGEMENT \& PRODUCTION (IJM\&P)

http://www.ijmp.jor.br

v. 11, n. 9, Special Edition (Baltic States), November 2020

ISSN: 2236-269X

DOI: 10.14807/ijmp.v11i9.1399

\subsection{Energy sector impact on Denmark economic security}

Denmark energy sector and economic security indicators correlations results are presented in Table 3.

Correlation analysis (Table 3) shows the results between Independent and Dependent indicators.

Links color gray are significant and using this data there were done regression analysis (see Table 4).

Table 3: Correlation (Denmark)

\begin{tabular}{|c|c|c|c|c|c|c|c|c|c|c|}
\hline$\frac{\text { Dependent }(\mathrm{Y})}{\text { Independent }(\mathrm{X})}$ & ESGd & ESIc & ESExp & ESImp & ESLog & ESBp & ESRd & ESTax & ESInv & ESGex \\
\hline ENProd & 0.025 & 0.493 & -0.932 & -0.947 & -0.370 & -0.855 & -0.622 & -0.302 & -0.010 & 0.196 \\
\hline ENImp & 0.067 & -0.535 & 0.638 & 0.592 & 0.718 & 0.648 & 0.251 & 0.477 & 0.025 & -0.144 \\
\hline ENExp & -0.187 & -0.390 & 0.833 & 0.880 & -0.012 & 0.666 & 0.555 & 0.040 & 0.118 & -0.299 \\
\hline ENSup & -0.055 & 0.520 & -0.818 & -0.825 & -0.471 & -0.767 & -0.585 & -0.510 & -0.009 & 0.108 \\
\hline ENTips & -0.216 & -0.702 & 0.924 & 0.938 & 0.298 & 0.735 & 0.607 & 0.187 & 0.189 & -0.348 \\
\hline ENOil & 0.019 & -0.192 & 0.727 & 0.749 & 0.191 & 0.702 & 0.835 & 0.016 & -0.113 & -0.033 \\
\hline ENCon & -0.283 & 0.289 & -0.694 & -0.686 & -0.545 & -0.729 & -0.428 & -0.708 & 0.168 & -0.115 \\
\hline ENInd & -0.390 & 0.097 & -0.592 & -0.592 & -0.407 & -0.803 & -0.627 & -0.626 & 0.381 & -0.302 \\
\hline ENTr & -0.433 & 0.114 & -0.723 & -0.695 & -0.540 & -0.816 & -0.452 & -0.611 & 0.394 & -0.310 \\
\hline ENRes & -0.094 & 0.336 & -0.426 & -0.424 & -0.459 & -0.295 & -0.053 & -0.627 & -0.137 & 0.098 \\
\hline ENServ & -0.270 & 0.334 & -0.391 & -0.385 & -0.598 & -0.452 & -0.151 & -0.699 & 0.080 & -0.061 \\
\hline ENOther & 0.358 & 0.666 & -0.830 & -0.857 & -0.192 & -0.650 & -0.561 & -0.286 & -0.356 & 0.474 \\
\hline ENOut & 0.209 & 0.699 & -0.837 & -0.842 & -0.276 & -0.583 & -0.580 & -0.202 & -0.241 & 0.288 \\
\hline
\end{tabular}

Correlation analysis (Table 3) shows the results between Independent and Dependent indicators.

Links color gray are significant and using this data there were done regression analysis (see Table 4).

Reflecting on Table 4 results, the demonstrated regression model formed correct $-\mathrm{R}$ square column shows above 50 percent of the included data. However, facts that correlations (see Table 3) present significant links, regression analysis shows that in Denmark only 2 economic security indicators - Isolation and Taxes are dependent on the energy sector's indicators Imports and Total final consumption. Import has positive impact on Isolation, Taxes - negative on Consumption.

\subsection{Energy sector impact on Germany economic security}

As in Denmark's case, it was done correlation analysis using Germany dataset. Germany energy sector and economic security indicators correlations results are presented in Table 5. 
DOI: 10.14807/ijmp.v11i9.1399

Links color gray are significant and using this data there were done regression analysis (see Table 6).

To follow the result in Table 6 it can be stated that Germany's Government consolidated gross debt depending on Import in the Energy sector. Energy production directly influences Actual individual consumption, Electricity output makes impact on Export, Energy supply Economic Isolation, and Industry - Investment.

Table 4: Regression (Denmark)

\begin{tabular}{|c|c|c|c|c|c|c|}
\hline Dependent variable & $\begin{array}{c}\text { Independent } \\
\text { variable }\end{array}$ & $\mathbf{R}$ & R Square & $\mathbf{t}$ & Sig. & Comment \\
\hline \multirow[t]{8}{*}{ ESExp } & ENProd & \multirow[t]{8}{*}{0.982} & \multirow[t]{8}{*}{0.964} & -1.168 & 0.363 & $\mathrm{P}>0.05$ \\
\hline & ENExp & & & -0.010 & 0.993 & $\mathrm{P}>0.05$ \\
\hline & ENSup & & & 1.068 & 0.397 & $\mathrm{P}>0.05$ \\
\hline & ENTips & & & 0.554 & 0.635 & $\mathrm{P}>0.05$ \\
\hline & ENOil & & & -1.436 & 0.288 & $\mathrm{P}>0.05$ \\
\hline & $\overline{\mathrm{ENTr}}$ & & & -0.528 & 0.650 & $\mathrm{P}>0.05$ \\
\hline & ENOther & & & 0.589 & 0.616 & $\mathrm{P}>0.05$ \\
\hline & ENOut & & & -0.349 & 0.760 & $\mathrm{P}>0.05$ \\
\hline \multirow[t]{5}{*}{ ESImp } & ENProd & \multirow[t]{5}{*}{0.983} & \multirow[t]{5}{*}{0.966} & -2.260 & 0.073 & $\mathrm{P}>0.05$ \\
\hline & ENExp & & & 2.033 & 0.098 & $\mathrm{P}>0.05$ \\
\hline & ENTips & & & 2.434 & 0.059 & $\mathrm{P}>0.05$ \\
\hline & ENOil & & & -1.879 & 0.119 & $\mathrm{P}>0.05$ \\
\hline & ENOther & & & 1.877 & 0.119 & $\mathrm{P}>0.05$ \\
\hline ESLog & ENImp & 0.718 & 0.516 & 3.096 & 0.013 & $P<0.05$ \\
\hline \multirow[t]{7}{*}{ ESBp } & ENProd & \multirow[t]{7}{*}{0.919} & \multirow[t]{7}{*}{0.845} & -1.099 & 0.352 & $\mathrm{P}>0.05$ \\
\hline & ENSup & & & -0.177 & 0.871 & $\mathrm{P}>0.05$ \\
\hline & ENTips & & & -0.169 & 0.877 & $\mathrm{P}>0.05$ \\
\hline & ENOil & & & -0.840 & 0.462 & $\mathrm{P}>0.05$ \\
\hline & $\overline{\text { ENCon }}$ & & & 0.483 & 0.662 & $\mathrm{P}>0.05$ \\
\hline & ENInd & & & -0.613 & 0.583 & $\mathrm{P}>0.05$ \\
\hline & $\overline{\mathrm{ENTr}}$ & & & -0.463 & 0.675 & $\mathrm{P}>0.05$ \\
\hline ESTax & ENCon & 0.708 & 0.501 & -3.006 & 0.015 & $P<0.05$ \\
\hline
\end{tabular}

Source: composed by authors 
INDEPENDENT JOURNAL OF MANAGEMENT \& PRODUCTION (IJM\&P)

http://www.ijmp.jor.br

v. 11, n. 9, Special Edition (Baltic States), November 2020

ISSN: 2236-269X

DOI: 10.14807/ijmp.v11i9.1399

Table 5: Correlation (Germany)

\begin{tabular}{|c|c|c|c|c|c|c|c|c|c|c|}
\hline$\frac{\text { Dependent }(\mathrm{Y})}{\text { Independent }(\mathrm{X})}$ & ESGd & ESIc & ESExp & ESImp & ESLog & ESBp & ESRd & ESTax & ESInv & ESGex \\
\hline ENProd & 0.402 & -0.862 & -0.951 & -0.814 & 0.711 & -0.776 & -0.968 & -0.751 & -0.620 & 0.473 \\
\hline ENImp & -0.717 & 0.209 & 0.666 & 0.500 & 0.022 & 0.565 & 0.572 & 0.668 & 0.531 & -0.560 \\
\hline ENExp & 0.688 & -0.407 & -0.848 & -0.640 & 0.361 & -0.763 & -0.791 & -0.743 & -0.558 & 0.575 \\
\hline ENSup & 0.234 & -0.727 & -0.699 & -0.593 & 0.898 & -0.595 & -0.789 & -0.571 & -0.424 & 0.259 \\
\hline ENTips & -0.450 & 0.801 & 0.947 & 0.793 & -0.697 & 0.794 & 0.981 & 0.761 & 0.623 & -0.466 \\
\hline ENOil & 0.363 & 0.720 & 0.435 & 0.313 & -0.680 & 0.392 & 0.534 & 0.062 & -0.127 & 0.272 \\
\hline ENCon & -0.322 & -0.085 & 0.208 & 0.202 & 0.351 & -0.005 & 0.152 & 0.235 & 0.362 & -0.105 \\
\hline ENInd & -0.227 & 0.051 & 0.500 & 0.640 & 0.165 & 0.330 & 0.335 & 0.119 & 0.730 & -0.684 \\
\hline ENTr & -0.697 & 0.575 & 0.915 & 0.707 & -0.367 & 0.779 & 0.879 & 0.811 & 0.695 & -0.588 \\
\hline ENRes & 0.168 & -0.481 & -0.611 & -0.560 & 0.575 & -0.661 & -0.572 & -0.280 & -0.379 & 0.575 \\
\hline ENServ & -0.183 & 0.043 & 0.299 & 0.160 & 0.076 & 0.258 & 0.235 & 0.220 & 0.010 & 0.008 \\
\hline ENOther & -0.307 & -0.062 & 0.152 & 0.276 & 0.174 & -0.254 & 0.193 & 0.147 & 0.567 & -0.117 \\
\hline ENOut & -0.508 & 0.212 & 0.708 & 0.636 & 0.012 & 0.640 & 0.558 & 0.506 & 0.605 & -0.663 \\
\hline
\end{tabular}

Source: composed by authors

Table 6: Regression (Germany)

\begin{tabular}{|c|c|c|c|c|c|c|}
\hline $\begin{array}{c}\text { Dependent } \\
\text { variable }\end{array}$ & $\begin{array}{l}\text { Independent } \\
\text { variable }\end{array}$ & $\mathbf{R}$ & R Square & t & Sig. & Comment \\
\hline ESGd & ENImp & 0.717 & 0.513 & -3.082 & 0.013 & $P<0.05$ \\
\hline \multirow[t]{4}{*}{ ESIc } & ENProd & \multirow[t]{4}{*}{0.940} & \multirow[t]{4}{*}{0.884} & -2.546 & 0.044 & $P<0.05$ \\
\hline & ENSup & & & 0.392 & 0.708 & $\mathrm{P}>0.05$ \\
\hline & ENTips & & & -1.496 & 0.185 & $\mathrm{P}>0.05$ \\
\hline & ENOil & & & 2.301 & 0.061 & $\mathrm{P}>0.05$ \\
\hline \multirow[t]{5}{*}{ ESExp } & ENProd & \multirow[t]{5}{*}{0.994} & \multirow[t]{5}{*}{0.988} & -2.338 & 0.067 & $\mathrm{P}>0.05$ \\
\hline & ENExp & & & -0.976 & 0.374 & $\mathrm{P}>0.05$ \\
\hline & ENTips & & & 1.450 & 0.207 & $\mathrm{P}>0.05$ \\
\hline & ENTr & & & -1.913 & 0.114 & $\mathrm{P}>0.05$ \\
\hline & ENOut & & & 3.743 & 0.013 & $P<0.05$ \\
\hline \multirow[t]{3}{*}{ ESImp } & ENProd & \multirow[t]{3}{*}{0.814} & \multirow[t]{3}{*}{0.663} & -0.847 & 0.425 & $\mathrm{P}>0.05$ \\
\hline & ENTips & & & -0.031 & 0.976 & $\mathrm{P}>0.05$ \\
\hline & ENTr & & & -0.011 & 0.991 & $\mathrm{P}>0.05$ \\
\hline \multirow[t]{2}{*}{ ESLog } & ENProd & \multirow[t]{2}{*}{0.899} & \multirow[t]{2}{*}{0.808} & -0.274 & 0.791 & $\mathrm{P}>0.05$ \\
\hline & ENSup & & & 3.545 & 0.008 & $P<0.05$ \\
\hline \multirow[t]{4}{*}{ ESBp } & ENProd & \multirow[t]{4}{*}{0.829} & \multirow[t]{4}{*}{0.687} & -0.308 & 0.768 & $\mathrm{P}>0.05$ \\
\hline & ENExp & & & -0.775 & 0.468 & $\mathrm{P}>0.05$ \\
\hline & ENTips & & & 0.188 & 0.857 & $\mathrm{P}>0.05$ \\
\hline & ENTr & & & -0.201 & 0.847 & $\mathrm{P}>0.05$ \\
\hline \multirow[t]{5}{*}{ ESRd } & ENProd & \multirow[t]{5}{*}{0.984} & \multirow[t]{5}{*}{0.969} & -0.891 & 0.414 & $\mathrm{P}>0.05$ \\
\hline & ENExp & & & -0.781 & 0.470 & $\mathrm{P}>0.05$ \\
\hline & ENSup & & & 0.285 & 0.787 & $\mathrm{P}>0.05$ \\
\hline & ENTips & & & 1.621 & 0.166 & $\mathrm{P}>0.05$ \\
\hline & ENTr & & & -0.569 & 0.594 & $\mathrm{P}>0.05$ \\
\hline \multirow[t]{4}{*}{ ESTax } & ENProd & \multirow[t]{4}{*}{0.816} & \multirow[t]{4}{*}{0.666} & -0.147 & 0.888 & $\mathrm{P}>0.05$ \\
\hline & ENExp & & & -0.113 & 0.914 & $\mathrm{P}>0.05$ \\
\hline & ENTips & & & 0.032 & 0.975 & $\mathrm{P}>0.05$ \\
\hline & ENTr & & & 0.651 & 0.539 & $\mathrm{P}>0.05$ \\
\hline ESInv & ENInd & 0.730 & 0.532 & 3.200 & 0.011 & $P<0.05$ \\
\hline
\end{tabular}

Source: composed by authors 
INDEPENDENT JOURNAL OF MANAGEMENT \& PRODUCTION (IJM\&P)

http://www.ijmp.jor.br

v. 11, n. 9, Special Edition (Baltic States), November 2020

ISSN: 2236-269X

DOI: 10.14807/ijmp.v11i9.1399

\subsection{Energy sector impact on Estonian economic security}

Correlation analysis was done also with the Estonian dataset. The results are presenting in Table 7.

Significant links between Energy sector indicators and country's economic security indicators are colored grey.

Referring link in Table 7, authors prepared regression analysis (see Table 8).

Eight from ten economic security indicators are significantly dependent on various indicators describing the energy sector in Estonia (see Table 8).

Table 7: Correlation (Estonia)

\begin{tabular}{lcccccccccc}
\hline \multicolumn{1}{c}{ Dependent (Y) } & ESGd & ESIc & ESExp & ESImp & ESLog & ESBp & ESRd & ESTax & ESInv & ESGex \\
\cline { 4 - 4 } Independent (X) & & & & & & & & & & \\
ENProd & 0.712 & 0.768 & 0.855 & 0.845 & -0.760 & 0.491 & 0.004 & -0.158 & -0.150 & -0.597 \\
ENImp & 0.732 & 0.646 & 0.651 & 0.716 & -0.694 & -0.044 & -0.074 & -0.144 & 0.280 & -0.279 \\
ENExp & -0.797 & -0.886 & -0.792 & -0.802 & 0.920 & -0.429 & 0.169 & -0.060 & 0.157 & 0.378 \\
ENSup & 0.450 & 0.462 & 0.656 & 0.649 & -0.427 & 0.031 & 0.038 & -0.474 & 0.165 & -0.772 \\
ENTips & 0.100 & 0.245 & -0.194 & -0.164 & -0.329 & 0.083 & -0.315 & 0.581 & -0.109 & 0.549 \\
ENCon & -0.530 & -0.114 & -0.149 & -0.088 & 0.257 & -0.868 & -0.206 & -0.522 & 0.673 & -0.152 \\
ENInd & -0.567 & -0.603 & -0.321 & -0.267 & 0.667 & -0.806 & 0.254 & -0.624 & 0.711 & -0.143 \\
ENTr & -0.055 & 0.710 & 0.473 & 0.487 & -0.591 & -0.195 & -0.362 & -0.170 & 0.162 & -0.345 \\
ENRes & -0.511 & -0.487 & -0.379 & -0.455 & 0.608 & -0.092 & 0.145 & 0.086 & -0.177 & 0.367 \\
ENServ & 0.513 & 0.820 & 0.327 & 0.363 & -0.888 & 0.245 & -0.681 & 0.365 & -0.289 & -0.107 \\
ENOther & 0.035 & 0.470 & 0.143 & 0.240 & -0.385 & -0.540 & -0.556 & -0.281 & 0.562 & -0.173 \\
ENOut & 0.263 & 0.290 & 0.687 & 0.628 & -0.213 & 0.195 & 0.323 & -0.532 & 0.023 & -0.764 \\
\hline
\end{tabular}

Source: composed by authors

Table 8: Regression (Estonia)

\begin{tabular}{|c|c|c|c|c|c|c|}
\hline $\begin{array}{c}\text { Dependent } \\
\text { variable }\end{array}$ & $\begin{array}{l}\text { Independent } \\
\text { variable }\end{array}$ & $\mathbf{R}$ & R Square & $\mathbf{t}$ & Sig. & Comment \\
\hline \multirow[t]{3}{*}{ ESGd } & ENProd & \multirow[t]{3}{*}{0.824} & \multirow[t]{3}{*}{0.679} & 0.631 & 0.548 & $\mathrm{P}>0.05$ \\
\hline & ENImp & & & 0.967 & 0.366 & $\mathrm{P}>0.05$ \\
\hline & ENExp & & & -0.310 & 0.766 & $\mathrm{P}>0.05$ \\
\hline \multirow[t]{5}{*}{ ESIc } & ENProd & \multirow[t]{5}{*}{0.954} & \multirow[t]{5}{*}{0.911} & 0.638 & 0.552 & $\mathrm{P}>0.05$ \\
\hline & ENImp & & & 0.189 & 0.858 & $\mathrm{P}>0.05$ \\
\hline & ENExp & & & -0.383 & 0.717 & $\mathrm{P}>0.05$ \\
\hline & ENTr & & & 1.731 & 0.144 & $\mathrm{P}>0.05$ \\
\hline & ENServ & & & 1.006 & 0.361 & $\mathrm{P}>0.05$ \\
\hline \multirow[t]{3}{*}{ ESExp } & ENProd & \multirow[t]{3}{*}{0.912} & \multirow[t]{3}{*}{0.832} & 2.689 & 0.031 & $P<0.05$ \\
\hline & ENImp & & & 2.037 & 0.081 & $\mathrm{P}>0.05$ \\
\hline & ENExp & & & 1.028 & 0.338 & $\mathrm{P}>0.05$ \\
\hline \multirow[t]{3}{*}{ ESImp } & ENProd & \multirow[t]{3}{*}{0.971} & \multirow[t]{3}{*}{0.942} & 2.689 & 0.031 & $P<0.05$ \\
\hline & ENImp & & & 2.037 & 0.081 & $\mathrm{P}>0.05$ \\
\hline & ENExp & & & 1.028 & 0.338 & $\mathrm{P}>0.05$ \\
\hline \multirow[t]{3}{*}{ ESLog } & ENProd & \multirow[t]{3}{*}{0.971} & \multirow[t]{3}{*}{0.942} & -0.631 & 0.548 & $\mathrm{P}>0.05$ \\
\hline & ENExp & & & 1.674 & 0.138 & $\mathrm{P}>0.05$ \\
\hline & ENServ & & & -3.307 & 0.013 & $P<0.05$ \\
\hline \multirow[t]{2}{*}{ ESBp } & ENCon & \multirow[t]{2}{*}{0.902} & \multirow[t]{2}{*}{0.813} & -2.643 & 0.030 & $P<0.05$ \\
\hline & ENInd & & & -1.585 & 0.152 & $\mathrm{P}>0.05$ \\
\hline ESInv & ENInd & 0.711 & 0.506 & 3.036 & 0.014 & $P<0.05$ \\
\hline
\end{tabular}


INDEPENDENT JOURNAL OF MANAGEMENT \& PRODUCTION (IJM\&P)

http://www.ijmp.jor.br

v. 11, n. 9, Special Edition (Baltic States), November 2020

ISSN: 2236-269X

DOI: 10.14807/ijmp.v11i9.1399

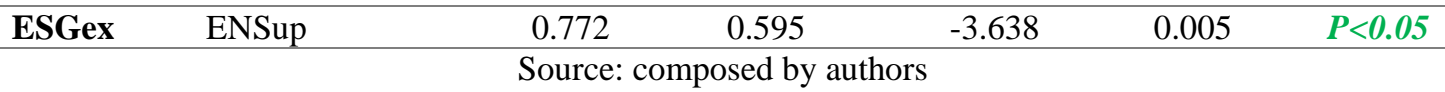

Export and Import are depending on Energy production, energy sector's indicator Commercial and public services do impact on Isolation, energy Consumption influences balance of payments, Industry effects on Investment, and Total primary energy supply directly powers to Total general government expenditure.

\subsection{Energy sector impact on Latvian economic security}

The authors have done correlation analysis with the Latvian dataset. Correlation results are presenting in Table 9.

Table 9: Correlation (Latvia)

\begin{tabular}{lcccccccccc}
\hline \multicolumn{1}{l}{ Dependent (Y) } & \multirow{2}{\text{Independent(X)}}{ ESGd } & ESIc & ESExp & ESImp & ESLog & ESBp & ESRd & ESTax & ESInv & ESGex \\
ENProd & 0.277 & 0.765 & 0.643 & 0.515 & -0.499 & 0.322 & -0.022 & 0.867 & -0.435 & -0.389 \\
ENImp & 0.094 & 0.650 & 0.598 & 0.544 & -0.227 & 0.130 & -0.048 & 0.659 & -0.223 & -0.604 \\
ENExp & -0.334 & -0.761 & -0.702 & -0.577 & 0.485 & -0.242 & -0.022 & -0.917 & 0.521 & 0.549 \\
ENSup & -0.419 & 0.172 & 0.023 & -0.028 & -0.235 & -0.244 & 0.069 & -0.053 & 0.422 & 0.202 \\
ENTips & -0.150 & -0.589 & -0.569 & -0.493 & 0.396 & 0.028 & -0.019 & -0.686 & 0.321 & 0.608 \\
ENCon & -0.470 & -0.283 & -0.408 & -0.361 & 0.000 & -0.274 & -0.073 & -0.464 & 0.561 & 0.408 \\
ENInd & 0.544 & 0.415 & 0.803 & 0.781 & 0.017 & -0.062 & 0.525 & 0.572 & -0.347 & -0.389 \\
ENTr & -0.648 & 0.141 & -0.335 & -0.455 & -0.620 & -0.205 & -0.364 & 0.041 & 0.328 & 0.137 \\
ENRes & -0.241 & -0.710 & -0.683 & -0.549 & 0.481 & -0.030 & -0.085 & -0.867 & 0.442 & 0.627 \\
ENServ & -0.203 & 0.462 & 0.436 & 0.488 & -0.287 & -0.375 & 0.117 & 0.354 & 0.338 & -0.422 \\
ENOther & -0.051 & 0.894 & 0.762 & 0.626 & -0.618 & -0.178 & 0.009 & 0.907 & -0.157 & -0.737 \\
ENOut & 0.406 & 0.311 & 0.305 & 0.167 & -0.434 & 0.316 & -0.230 & 0.555 & -0.511 & 0.040 \\
\hline
\end{tabular}

Source: composed by authors

Significant links between Latvian Energy sector indicators and country’s economic security indicators also are colored grey.

In accordance with to correlation results presented in Table 9, the authors did regression analysis and put it to Table 10.

\begin{tabular}{|c|c|c|c|c|c|c|}
\hline $\begin{array}{l}\text { Dependent } \\
\text { variable }\end{array}$ & $\begin{array}{c}\text { Independent } \\
\text { variable }\end{array}$ & $\mathbf{R}$ & R Square & $\mathbf{t}$ & Sig. & Comment \\
\hline \multirow[t]{4}{*}{ ESIc } & ENProd & 0.931 & 0.867 & 0.027 & 0.979 & $\mathrm{P}>0.05$ \\
\hline & ENExp & & & -0.470 & 0.655 & $\mathrm{P}>0.05$ \\
\hline & ENRes & & & 0.835 & 0.436 & $\mathrm{P}>0.05$ \\
\hline & ENOther & & & 2.862 & 0.029 & $P<0.05$ \\
\hline \multirow[t]{3}{*}{ ESExp } & ENExp & 0.896 & 0.803 & 0.523 & 0.617 & $\mathrm{P}>0.05$ \\
\hline & ENInd & & & 2.707 & 0.030 & $P<0.05$ \\
\hline & ENOther & & & 1.941 & 0.093 & $\mathrm{P}>0.05$ \\
\hline ESImp & ENInd & 0.781 & 0.609 & 3.746 & 0.005 & $P<0.05$ \\
\hline \multirow[t]{3}{*}{ ESTax } & ENProd & 0.965 & 0.931 & 0.883 & 0.411 & $\mathrm{P}>0.05$ \\
\hline & ENExp & & & -0.016 & 0.988 & $\mathrm{P}>0.05$ \\
\hline & ENRes & & & -0.295 & 0.778 & $\mathrm{P}>0.05$ \\
\hline
\end{tabular}


INDEPENDENT JOURNAL OF MANAGEMENT \& PRODUCTION (IJM\&P)

http://www.ijmp.jor.br

v. 11, n. 9, Special Edition (Baltic States), November 2020

ISSN: 2236-269X

DOI: 10.14807/ijmp.v11i9.1399

\begin{tabular}{lllllll}
\hline & ENOther & & & 1.558 & 0.170 & $\mathrm{P}>0.05$ \\
\hline ESGex & ENOther & 0.737 & 0.542 & -3.266 & 0.010 & $\boldsymbol{P}<0.05$ \\
\hline
\end{tabular}

Source: composed by authors

Estonian economic security indicator Actual individual consumption is depending on Energy other consumption, Export and Import are influenced by energy Industry, and energy other consumption does impact on Total general government expenditure, which is the country's economic security indicator.

\subsection{Energy sector impact on Lithuanian economic security}

Lithuanian energy sector and economic security indicators correlations results are presented in Table 11.

Table 11: Correlation (Lithuania)

\begin{tabular}{lcccccccccc}
\hline \multicolumn{1}{c}{ Dependent (Y) } & \multirow{2}{\text{Independent(X)}}{ ESGd } & \multirow{2}{*}{ ESIc } & ESExp & ESImp & ESLog & ESBp & ESRd & ESTax & ESInv & ESGex \\
ENProd & -0.833 & -0.256 & -0.714 & -0.697 & -0.540 & -0.391 & -0.478 & 0.683 & 0.498 & 0.421 \\
ENImp & 0.405 & 0.582 & 0.545 & 0.446 & 0.305 & -0.118 & 0.121 & -0.066 & 0.085 & -0.580 \\
ENExp & -0.380 & -0.527 & -0.229 & -0.105 & 0.139 & 0.006 & -0.093 & -0.103 & -0.056 & 0.504 \\
ENSup & -0.947 & -0.149 & -0.520 & -0.497 & -0.307 & -0.625 & -0.556 & 0.699 & 0.685 & 0.324 \\
ENTips & 0.855 & 0.496 & 0.749 & 0.672 & 0.439 & 0.441 & 0.566 & -0.536 & -0.402 & -0.600 \\
ENOil & 0.303 & 0.660 & 0.025 & -0.185 & -0.134 & 0.112 & 0.352 & 0.503 & 0.121 & -0.478 \\
ENCon & -0.020 & 0.815 & 0.553 & 0.406 & 0.201 & -0.320 & 0.171 & 0.285 & 0.553 & -0.728 \\
ENInd & 0.272 & 0.633 & 0.913 & 0.859 & 0.396 & -0.057 & 0.401 & -0.328 & 0.192 & -0.751 \\
ENTr & -0.006 & 0.883 & 0.211 & -0.006 & -0.140 & -0.130 & 0.140 & 0.594 & 0.541 & -0.726 \\
ENRes & -0.556 & -0.682 & -0.482 & -0.301 & 0.216 & -0.273 & -0.819 & 0.052 & -0.077 & 0.773 \\
ENServ & -0.131 & 0.612 & 0.215 & 0.129 & 0.156 & 0.010 & -0.282 & 0.375 & 0.216 & -0.403 \\
ENOther & 0.107 & 0.663 & 0.722 & 0.620 & 0.308 & -0.358 & 0.398 & -0.015 & 0.455 & -0.675 \\
ENOut & -0.835 & -0.504 & -0.753 & -0.676 & -0.469 & -0.431 & -0.552 & 0.521 & 0.389 & 0.593 \\
\hline
\end{tabular}

Strong correlations between the Lithuanian energy sector and economic security indicators were colored grey. Based on these figures the authors prepared regression analysis shown in Table 12. 
INDEPENDENT JOURNAL OF MANAGEMENT \& PRODUCTION (IJM\&P)

http://www.ijmp.jor.br

v. 11, n. 9, Special Edition (Baltic States), November 2020

ISSN: 2236-269X

DOI: 10.14807/ijmp.v11i9.1399

Table 12: Regression (Lithuania)

\begin{tabular}{|c|c|c|c|c|c|c|}
\hline $\begin{array}{l}\text { Dependent } \\
\text { variable }\end{array}$ & $\begin{array}{l}\text { Independent } \\
\text { variable }\end{array}$ & $\mathbf{R}$ & R Square & t & Sig. & Comment \\
\hline \multirow[t]{4}{*}{ ESGd } & ENProd & \multirow[t]{4}{*}{0.970} & \multirow[t]{4}{*}{0.941} & 1.420 & 0.206 & $\mathrm{P}>0.05$ \\
\hline & ENSup & & & -3.008 & 0.024 & $P<0.05$ \\
\hline & ENTips & & & 1.014 & 0.350 & $\mathrm{P}>0.05$ \\
\hline & ENOut & & & 0.760 & 0.476 & $\mathrm{P}>0.05$ \\
\hline \multirow[t]{2}{*}{ ESIc } & ENCon & \multirow[t]{2}{*}{0.893} & \multirow[t]{2}{*}{0.798} & 0.851 & 0.419 & $\mathrm{P}>0.05$ \\
\hline & ENTr & & & 2.300 & 0.050 & $P<0.05$ \\
\hline \multirow{5}{*}{ ESExp } & ENProd & \multirow{5}{*}{0.953} & \multirow{5}{*}{0.908} & -1.034 & 0.348 & $\mathrm{P}>0.05$ \\
\hline & ENTips & & & 0.461 & 0.664 & $\mathrm{P}>0.05$ \\
\hline & ENInd & & & 2.422 & 0.060 & $\mathrm{P}>0.05$ \\
\hline & ENOther & & & 0.385 & 0.716 & $\mathrm{P}>0.05$ \\
\hline & ENOut & & & 0.572 & 0.592 & $\mathrm{P}>0.05$ \\
\hline ESImp & ENInd & 0.859 & 0.737 & 5.022 & 0.001 & $P<0.05$ \\
\hline ESRd & ENRes & 0.819 & 0.671 & -4.280 & 0.002 & $P<0.05$ \\
\hline \multirow[t]{4}{*}{ ESGex } & ENCon & \multirow[t]{4}{*}{0.96} & \multirow[t]{4}{*}{0.922} & 1.440 & 0.200 & $\mathrm{P}>0.05$ \\
\hline & ENInd & & & -2.966 & 0.025 & $P<0.05$ \\
\hline & ENTr & & & -2.081 & 0.083 & $\mathrm{P}>0.05$ \\
\hline & ENRes & & & 2.022 & 0.090 & $\mathrm{P}>0.05$ \\
\hline
\end{tabular}

Source: composed by authors

Government consolidated gross debt in Lithuania is powered by Total primary energy supply, and energy sector indicator Transport influences on Actual individual consumption. Economic security indicators Import and Total general government expenditure are strongly depending on Energy Industry, Research and development - on Residential.

\subsection{Energy sector impact on Poland economic security}

Table 13 contains correlations results between Poland energy sector and economic security indicators.

Table 13: Correlation (Poland)

\begin{tabular}{lcccccccccc}
\hline Dependent (Y) & \multirow{2}{*}{$\begin{array}{l}\text { Independent (X) } \\
\text { ESGd }\end{array}$} & ESIc & ESExp & ESImp & ESLog & ESBp & ESRd & ESTax & ESInv & ESGex \\
ENProd & 0.311 & -0.409 & -0.459 & -0.370 & -0.151 & -0.492 & -0.646 & -0.498 & 0.555 & 0.364 \\
ENImp & -0.168 & 0.794 & 0.829 & 0.775 & 0.452 & 0.584 & 0.842 & 0.753 & -0.704 & -0.640 \\
ENExp & -0.410 & -0.314 & -0.590 & -0.572 & -0.628 & -0.755 & -0.589 & -0.109 & 0.603 & 0.730 \\
ENSup & -0.017 & 0.709 & 0.573 & 0.542 & 0.426 & 0.176 & 0.448 & 0.637 & -0.505 & -0.249 \\
ENTips & -0.362 & 0.326 & 0.507 & 0.418 & 0.247 & 0.774 & 0.730 & 0.579 & -0.630 & -0.686 \\
ENOil & -0.469 & -0.155 & -0.061 & -0.184 & -0.041 & 0.337 & 0.160 & 0.316 & -0.069 & -0.187 \\
ENCon & -0.049 & 0.688 & 0.671 & 0.614 & 0.473 & 0.445 & 0.643 & 0.676 & -0.701 & -0.447 \\
ENInd & -0.181 & 0.874 & 0.879 & 0.841 & 0.680 & 0.651 & 0.805 & 0.841 & -0.721 & -0.771 \\
ENTr & -0.186 & 0.647 & 0.681 & 0.613 & 0.431 & 0.529 & 0.702 & 0.722 & -0.688 & -0.544 \\
ENRes & 0.428 & -0.104 & -0.265 & -0.242 & -0.132 & -0.414 & -0.319 & -0.314 & 0.001 & 0.596 \\
ENServ & 0.553 & -0.155 & -0.207 & -0.212 & -0.105 & -0.355 & -0.273 & -0.269 & -0.070 & 0.438 \\
ENOther & -0.275 & 0.773 & 0.794 & 0.725 & 0.548 & 0.605 & 0.770 & 0.845 & -0.655 & -0.686 \\
ENOut & 0.250 & 0.787 & 0.941 & 0.910 & 0.787 & 0.746 & 0.848 & 0.585 & -0.842 & -0.811 \\
\hline
\end{tabular}

\footnotetext{
Source: composed by authors
} 
INDEPENDENT JOURNAL OF MANAGEMENT \& PRODUCTION (IJM\&P)

http://www.ijmp.jor.br

v. 11, n. 9, Special Edition (Baltic States), November 2020

ISSN: 2236-269X

DOI: 10.14807/ijmp.v11i9.1399

Following the same examination structure that was done with other countries, the authors supplied regression analysis results in Table 14.

Although Table 13 shows a lot of significant correlations, regression analysis presents several significant dependencies between the Energy sector and economic security indicators in Poland.

So, Import, Export, Isolation, R\&D are influenced by Electricity output, Balance of payments are depending on energy Export and Electricity, CHP and heat plants. Electricity, CHP and heat plants also make an impact on R\&D, as well as energy Export makes the force on Total general government expenditure.

\subsection{Energy sector impact on Finland economic security}

This article's author present Finland energy sector and economic security indicators correlations results in Table 15.

Finland dataset correlations results in Table 15 presented not a lot of significant links, even so, authors have done regression analysis which results are shown in Table 16.

Table 14: Regression (Poland)

\begin{tabular}{|c|c|c|c|c|c|c|}
\hline $\begin{array}{c}\text { Dependent } \\
\text { variable }\end{array}$ & $\begin{array}{c}\text { Independent } \\
\text { variable }\end{array}$ & $\mathbf{R}$ & R Square & $\mathbf{t}$ & Sig. & Comment \\
\hline \multirow[t]{5}{*}{ ESIc } & ENImp & \multirow[t]{5}{*}{0.906} & \multirow[t]{5}{*}{0.820} & 0.297 & 0.779 & $\mathrm{P}>0.05$ \\
\hline & ENSup & & & 0.562 & 0.599 & $\mathrm{P}>0.05$ \\
\hline & ENInd & & & 1.873 & 0.120 & $\mathrm{P}>0.05$ \\
\hline & ENOther & & & -1.087 & 0.327 & $\mathrm{P}>0.05$ \\
\hline & ENOut & & & 0.115 & 0.913 & $\mathrm{P}>0.05$ \\
\hline \multirow[t]{4}{*}{ ESExp } & ENImp & \multirow[t]{4}{*}{0.959} & \multirow[t]{4}{*}{0.919} & 0.673 & 0.526 & $\mathrm{P}>0.05$ \\
\hline & ENInd & & & 1.385 & 0.215 & $\mathrm{P}>0.05$ \\
\hline & ENOther & & & -1.186 & 0.280 & $\mathrm{P}>0.05$ \\
\hline & ENOut & & & 2.753 & 0.033 & $P<0.05$ \\
\hline \multirow[t]{3}{*}{ ESImp } & ENImp & \multirow[t]{3}{*}{0.917} & \multirow[t]{3}{*}{0.841} & -0.373 & 0.720 & $\mathrm{P}>0.05$ \\
\hline & ENInd & & & 0.741 & 0.483 & $\mathrm{P}>0.05$ \\
\hline & ENOut & & & 2.422 & 0.046 & $P<0.05$ \\
\hline ESLog & ENOut & 0.787 & 0.619 & 3.821 & 0.004 & $P<0.05$ \\
\hline \multirow[t]{3}{*}{ ESBp } & ENExp & \multirow[t]{3}{*}{0.943} & \multirow[t]{3}{*}{0.889} & -2.596 & 0.036 & $P<0.05$ \\
\hline & ENTips & & & 3.285 & 0.013 & $P<0.05$ \\
\hline & ENOut & & & 1.754 & 0.123 & $\mathrm{P}>0.05$ \\
\hline \multirow[t]{6}{*}{ ESRd } & ENImp & \multirow[t]{6}{*}{0.986} & \multirow[t]{6}{*}{0.973} & 3.766 & 0.020 & $P<0.05$ \\
\hline & ENTips & & & 4.464 & 0.011 & $P<0.05$ \\
\hline & ENInd & & & -0.283 & 0.791 & $\mathrm{P}>0.05$ \\
\hline & ENTr & & & -2.524 & 0.065 & $\mathrm{P}>0.05$ \\
\hline & ENOther & & & -1.252 & 0.279 & $\mathrm{P}>0.05$ \\
\hline & ENOut & & & 3.333 & 0.029 & $P<0.05$ \\
\hline \multirow[t]{4}{*}{ ESTax } & ENImp & \multirow[t]{4}{*}{0.873} & \multirow[t]{4}{*}{0.762} & -0.336 & 0.749 & $\mathrm{P}>0.05$ \\
\hline & ENInd & & & 0.547 & 0.604 & $\mathrm{P}>0.05$ \\
\hline & ENTr & & & -0.476 & 0.651 & $\mathrm{P}>0.05$ \\
\hline & ENOther & & & 1.152 & 0.293 & $\mathrm{P}>0.05$ \\
\hline \multirow[t]{2}{*}{ ESInv } & ENImp & \multirow[t]{2}{*}{0.779} & \multirow[t]{2}{*}{0.607} & -0.191 & 0.855 & $\mathrm{P}>0.05$ \\
\hline & ENInd & & & -1.252 & 0.257 & $\mathrm{P}>0.05$ \\
\hline
\end{tabular}


INDEPENDENT JOURNAL OF MANAGEMENT \& PRODUCTION (IJM\&P)

http://www.ijmp.jor.br

v. 11, n. 9, Special Edition (Baltic States), November 2020

ISSN: 2236-269X

DOI: 10.14807/ijmp.v11i9.1399

\begin{tabular}{lllrrrr}
\hline & ENTr & & -0.760 & 0.476 & $\mathrm{P}>0.05$ \\
\cline { 2 - 5 } & ENOther & & 1.036 & 0.340 & $\mathrm{P}>0.05$ \\
\hline \multirow{2}{*}{ ESGex } & ENExp & 0.911 & 0.829 & 2.515 & 0.040 & $\boldsymbol{P}<0.05$ \\
& ENInd & & -1.644 & 0.144 & $\mathrm{P}>0.05$ \\
\cline { 4 - 7 } & ENOut & & -0.111 & 0.914 & $\mathrm{P}>0.05$ \\
\hline
\end{tabular}

Source: composed by authors

Table 15: Correlation (Finland)

\begin{tabular}{|c|c|c|c|c|c|c|c|c|c|c|}
\hline $\begin{array}{c}\text { Dependent (Y) } \\
\text { Independent (X) }\end{array}$ & ESGd & ESIc & ESExp & ESImp & ESLog & ESBp & ESRd & ESTax & ESInv & ESGex \\
\hline ENProd & 0.756 & 0.602 & 0.757 & 0.633 & -0.221 & -0.637 & -0.723 & 0.551 & -0.147 & 0.431 \\
\hline ENImp & -0.578 & -0.157 & -0.249 & -0.088 & 0.184 & 0.293 & 0.543 & -0.319 & 0.183 & -0.343 \\
\hline ENEXp & -0.707 & -0.744 & -0.574 & -0.514 & 0.303 & 0.704 & 0.681 & -0.752 & 0.146 & -0.484 \\
\hline ENSup & -0.598 & -0.424 & -0.192 & -0.081 & 0.518 & 0.443 & 0.597 & -0.680 & 0.311 & -0.518 \\
\hline ENTips & 0.659 & 0.270 & 0.450 & 0.276 & -0.073 & -0.472 & -0.901 & 0.609 & 0.147 & 0.150 \\
\hline ENOil & 0.589 & 0.427 & 0.743 & 0.670 & -0.468 & -0.537 & -0.638 & 0.647 & -0.159 & 0.291 \\
\hline ENCon & -0.082 & -0.168 & 0.186 & 0.176 & 0.529 & 0.101 & -0.058 & -0.204 & 0.368 & -0.379 \\
\hline ENInd & -0.125 & -0.263 & 0.311 & 0.282 & 0.460 & 0.061 & -0.185 & -0.063 & 0.475 & -0.589 \\
\hline ENTr & -0.623 & -0.346 & -0.091 & 0.029 & 0.523 & 0.338 & 0.584 & -0.673 & 0.469 & -0.614 \\
\hline ENRes & -0.107 & -0.035 & -0.147 & -0.099 & 0.317 & 0.148 & 0.311 & -0.437 & 0.066 & 0.042 \\
\hline ENServ & 0.192 & 0.383 & 0.206 & 0.260 & -0.004 & -0.217 & 0.142 & -0.168 & -0.110 & 0.359 \\
\hline ENOther & 0.346 & 0.036 & -0.043 & -0.164 & 0.021 & -0.009 & -0.534 & 0.476 & -0.159 & 0.166 \\
\hline ENOut & -0.778 & -0.647 & -0.462 & -0.355 & 0.550 & 0.698 & 0.752 & -0.822 & 0.278 & -0.587 \\
\hline
\end{tabular}

Source: composed by authors

Finland dataset correlations results in Table 15 presented not a lot of significant links, even so, authors have done regression analysis which results are shown in Table 16.

Table 16: Regression (Finland)

\begin{tabular}{|c|c|c|c|c|c|c|}
\hline $\begin{array}{c}\text { Dependent } \\
\text { variable }\end{array}$ & $\begin{array}{l}\text { Independent } \\
\text { variable }\end{array}$ & $\mathbf{R}$ & R Square & $\mathbf{t}$ & Sig. & Comment \\
\hline \multirow[t]{3}{*}{ ESGd } & ENProd & 0.887 & 0.786 & 1.776 & 0.119 & $\mathrm{P}>0.05$ \\
\hline & ENExp & & & -0.224 & 0.829 & $\mathrm{P}>0.05$ \\
\hline & ENOut & & & -2.303 & 0.055 & $\mathrm{P}>0.05$ \\
\hline ESIc & ENExp & 0.744 & 0.554 & -3.344 & 0.009 & $P<0.05$ \\
\hline \multirow[t]{2}{*}{ ESExp } & ENProd & 0.837 & 0.700 & 1.985 & 0.082 & $\mathrm{P}>0.05$ \\
\hline & ENOil & & & 1.847 & 0.102 & $\mathrm{P}>0.05$ \\
\hline \multirow[t]{3}{*}{ ESRd } & ENProd & 0.941 & 0.885 & -2.056 & 0.079 & $\mathrm{P}>0.05$ \\
\hline & ENTips & & & -3.109 & 0.017 & $P<0.05$ \\
\hline & ENOut & & & 0.176 & 0.865 & $\mathrm{P}>0.05$ \\
\hline \multirow[t]{2}{*}{ ESTax } & ENExp & 0.88 & 0.775 & -1.872 & 0.098 & $\mathrm{P}>0.05$ \\
\hline & ENOut & & & -2.726 & 0.026 & $P<0.05$ \\
\hline
\end{tabular}

Source: composed by authors

Finland energy Export indicator impacts on Actual individual consumption, CHP and heat plants. Electricity directly links with R\&D, and Tax indicator is depending on Electricity output.

\subsection{Energy sector impact on Sweden economic security}

As in other 7 countries' case in this reaserch, it was done correlation analysis using Sweden dataset. Sweden energy sector and economic security indicators correlations results are presented in Table 17. 
DOI: 10.14807/ijmp.v11i9.1399

Table 17: Correlation (Sweden)

\begin{tabular}{|c|c|c|c|c|c|c|c|c|c|c|}
\hline $\begin{array}{l}\text { Dependent }(\mathrm{Y}) \\
\text { Independent }(\mathrm{X})\end{array}$ & ESGd & ESIc & ESExp & ESImp & ESLog & ESBp & ESRd & ESTax & ESInv & ESGex \\
\hline ENProd & 0.083 & 0.678 & 0.877 & 0.895 & -0.441 & -0.583 & -0.208 & -0.033 & 0.446 & -0.479 \\
\hline ENImp & -0.050 & -0.193 & 0.197 & 0.243 & 0.230 & -0.530 & 0.113 & 0.566 & 0.753 & -0.781 \\
\hline ENExp & -0.265 & -0.084 & -0.506 & -0.577 & 0.214 & 0.837 & -0.042 & -0.435 & -0.754 & 0.687 \\
\hline ENSup & -0.591 & 0.370 & 0.289 & 0.232 & 0.038 & 0.222 & -0.168 & -0.144 & -0.046 & -0.141 \\
\hline ENTips & 0.076 & -0.513 & -0.697 & -0.730 & 0.185 & 0.384 & 0.038 & -0.083 & -0.452 & 0.221 \\
\hline ENOil & 0.349 & -0.100 & -0.064 & -0.047 & -0.179 & -0.336 & -0.370 & -0.227 & -0.128 & -0.022 \\
\hline ENCon & -0.569 & -0.118 & 0.105 & 0.077 & 0.171 & -0.092 & 0.042 & 0.287 & 0.304 & -0.478 \\
\hline ENInd & -0.700 & -0.046 & -0.065 & -0.158 & 0.405 & 0.559 & 0.021 & -0.173 & -0.090 & -0.273 \\
\hline ENTr & 0.088 & -0.233 & 0.221 & 0.309 & 0.138 & -0.694 & 0.254 & 0.697 & 0.869 & -0.692 \\
\hline ENRes & -0.341 & 0.496 & 0.511 & 0.445 & -0.622 & -0.318 & -0.508 & -0.341 & -0.219 & -0.163 \\
\hline ENServ & -0.206 & -0.393 & -0.492 & -0.527 & 0.289 & 0.203 & -0.056 & 0.260 & -0.193 & 0.032 \\
\hline ENOther & -0.493 & -0.542 & -0.275 & -0.238 & 0.643 & 0.169 & 0.596 & 0.674 & 0.536 & -0.211 \\
\hline ENOut & 0.079 & 0.607 & 0.843 & 0.844 & -0.455 & -0.537 & -0.201 & -0.122 & 0.413 & -0.584 \\
\hline
\end{tabular}

It may seem that the energy sector indicators make a lack of impact on the country's economic security factors. Having a little amount of significance, the authors of this article still decided to prepare a regression analysis declared in Table 18.

Table 18: Regression (Sweden)

\begin{tabular}{|c|c|c|c|c|c|c|}
\hline $\begin{array}{c}\text { Dependent } \\
\text { variable }\end{array}$ & $\begin{array}{l}\text { Independent } \\
\text { variable }\end{array}$ & $\mathbf{R}$ & R Square & $\mathbf{t}$ & Sig. & Comment \\
\hline \multirow[t]{2}{*}{ ESExp } & ENProd & 0.883 & 0.780 & 1.587 & 0.151 & $\mathrm{P}>0.05$ \\
\hline & ENOut & & & 0.632 & 0.545 & $\mathrm{P}>0.05$ \\
\hline \multirow[t]{3}{*}{ ESImp } & ENProd & 0.898 & 0.806 & 0.449 & 0.667 & $\mathrm{P}>0.05$ \\
\hline & ENTips & & & -0.166 & 0.873 & $\mathrm{P}>0.05$ \\
\hline & ENOut & & & 0.345 & 0.740 & $\mathrm{P}>0.05$ \\
\hline ESBp & ENExp & 0.837 & 0.701 & 4.590 & 0.001 & $P<0.05$ \\
\hline ESInv & ENTr & 0.869 & 0.754 & 5.259 & 0.001 & $P<0.05$ \\
\hline
\end{tabular}

From Table 18 it is understood that the Balances of payments in Sweden is depending on the energy sector Export indicator, and Investment is powered by Transport. 
INDEPENDENT JOURNAL OF MANAGEMENT \& PRODUCTION (IJM\&P)

http://www.ijmp.jor.br

v. 11, n. 9, Special Edition (Baltic States), November 2020

ISSN: 2236-269X

DOI: 10.14807/ijmp.v11i9.1399

Table 19: Energy sector impact on Baltic sea region EU countries' economic security

\begin{tabular}{|c|c|c|c|c|c|}
\hline $\begin{array}{c}\text { Independent } \\
\text { variable }\end{array}$ & Dependent variable & $\mathbf{t}$ & Sig. & Comment & Country \\
\hline \multirow[t]{2}{*}{ ENCon } & ESBp & -2.643 & 0.030 & $P<0.05$ & Estonia \\
\hline & ESTax & -3.006 & 0.015 & $P<0.05$ & Denmark \\
\hline \multirow[t]{4}{*}{ ENExp } & ESBp & -2.596 & 0.036 & $P<0.05$ & Poland \\
\hline & ESBp & 4.590 & 0.001 & $P<0.05$ & Sweden \\
\hline & ESGex & 2.515 & 0.040 & $P<0.05$ & Poland \\
\hline & ESIc & -3.344 & 0.009 & $P<0.05$ & Finland \\
\hline \multirow[t]{3}{*}{ ENImp } & ESGd & -3.082 & 0.013 & $P<0.05$ & Germany \\
\hline & ESLog & 3.096 & 0.013 & $P<0.05$ & Denmark \\
\hline & ESRd & 3.766 & 0.020 & $P<0.05$ & Poland \\
\hline \multirow[t]{6}{*}{ ENInd } & ESExp & 2.707 & 0.030 & $P<0.05$ & Latvia \\
\hline & ESGex & -2.966 & 0.025 & $P<0.05$ & Lithuania \\
\hline & ESImp & 3.746 & 0.005 & $P<0.05$ & Latvia \\
\hline & ESImp & 5.022 & 0.001 & $P<0.05$ & Lithuania \\
\hline & ESInv & 3.200 & 0.011 & $P<0.05$ & Germany \\
\hline & ESInv & 3.036 & 0.014 & $P<0.05$ & Estonia \\
\hline \multirow[t]{2}{*}{ ENOther } & ESGex & -3.266 & 0.010 & $P<0.05$ & Latvia \\
\hline & ESIc & 2.862 & 0.029 & $P<0.05$ & Latvia \\
\hline \multirow[t]{6}{*}{ ENOut } & ESExp & 3.743 & 0.013 & $P<0.05$ & Germany \\
\hline & ESExp & 2.753 & 0.033 & $P<0.05$ & Poland \\
\hline & ESImp & 2.422 & 0.046 & $P<0.05$ & Poland \\
\hline & ESLog & 3.821 & 0.004 & $P<0.05$ & Poland \\
\hline & ESRd & 3.333 & 0.029 & $P<0.05$ & Poland \\
\hline & ESTax & -2.726 & 0.026 & $P<0.05$ & Finland \\
\hline \multirow[t]{3}{*}{ ENProd } & ESExp & 2.689 & 0.031 & $P<0.05$ & Estonia \\
\hline & ESIC & -2.546 & 0.044 & $P<0.05$ & Germany \\
\hline & ESImp & 2.689 & 0.031 & $P<0.05$ & Estonia \\
\hline ENRes & ESRd & -4.280 & 0.002 & $P<0.05$ & Lithuania \\
\hline ENServ & ESLog & -3.307 & 0.013 & $P<0.05$ & Estonia \\
\hline \multirow[t]{3}{*}{ ENSup } & ESGd & -3.008 & 0.024 & $P<0.05$ & Lithuania \\
\hline & ESGex & -3.638 & 0.005 & $P<0.05$ & Estonia \\
\hline & ESLog & 3.545 & 0.008 & $P<0.05$ & Germany \\
\hline \multirow[t]{3}{*}{ ENTips } & ESBp & 3.285 & 0.013 & $P<0.05$ & Poland \\
\hline & ESRd & 4.464 & 0.011 & $P<0.05$ & Poland \\
\hline & ESRd & -3.109 & 0.017 & $P<0.05$ & Finland \\
\hline \multirow[t]{2}{*}{ ENTr } & ESIc & 2.300 & 0.050 & $P<0.05$ & Lithuania \\
\hline & ESInv & 5.259 & 0.001 & $P<0.05$ & Sweden \\
\hline
\end{tabular}

Table 19 shows energy sector indicators that influence economic security indicators in the Baltic sea region EU states. To conclude the results in this table it can be stated that most often countries' economic security factors are depended on Energy Export, Industry, Electricity output. Energy Import and Production have a pretty significant role in forming economic security.

Following eight countries' analysis results, the authors suggest not limited Lino Briguglio developed system indicators but to broaden research including indexes from the other economic schools.

\section{CONCLUSIONS}


DOI: 10.14807/ijmp.v11i9.1399

The authors have done reviewing economic security literature. Different approaches to economic security principles let to do some assumptions related to the country's economic security concept. Firstly, the country's economic security cannot be separated from other factors of the state's security dimensions such as political and military, economic, and human rights issues. Second, economic security at the macroeconomic level can be shown from the prism of external threats, suchlike countries' dependency on energy resources, poverty, unemployment, migration, and corruption.

Also, the authors have described the energy sector creating the general structure to reveal this sector's main activities as well as selected indicators that analyze energy sector.

To analyze the economic security at the macro level this article authors use BRIGULIO proposed method into two-level: economic vulnerability and resilience level. The authors have decided to use indicators that may describe this method in a better way.

Using the Baltic sea region EU states' datasets that include the indicators measuring the energy sector and the country's economic security, the authors have prepared correlation and regression analysis. The research has covered a period of 11 years (from 2008 - 2018 years) and applied for each EU country of the Baltic sea region. The results of the research were presented in Tables 3-19, as well as briefly declared in third article part. The main conclusion of research results is that most often countries' economic security factors are dependent on Energy Export, Industry, Electricity output. Energy Import and Production have a pretty significant role in forming economic security, too.

This research could serve as a basis for further SWOT and PEST analysis. 
DOI: 10.14807/ijmp.v11i9.1399

\section{REFERENCES}

AMERICAN PETROLEUM INSTITUTE. Available: <https://www.api.org/news-policyand-issues/natural-gas-solutions/what-is-natural-gas>. Access: 10 July 2020

ANGULO-GUERRERO, M. J.-M.-G. (2017) How Economic Freedom Affects Opportunity and Necessity Entrepreneurship in the OECD Countries. Journal of Business Research, v. 73, p. 30-37. DOI: https://doi.org/10.1016/j.jbusres.2016.11.017.

ARUMÄGI, E.; KALAMEES, T. (2020) Cost and Energy Reduction of a New ZEB Wooden Building. Energies, v. 13, p. 3570.

AUERBACH, A. (2018) Measuring the Effects of Corporate Tax Cuts. The Journal of Economic Perspectives, v. 32, n. 4, p. 97-120. Available: <www.jstor.org/stable/26513498>. Access: July 9, 2020.

BELLIDO, J. M.; ROMERO, B. P. (2015) ESCO formation as enabling factor for smart cities development in European Union (UE): Spain case analysis. Independent Journal of Management \& Production, v. 6, n. 4, p. 866-884.

DOI: http://dx.doi.org/10.14807/ijmp.v6i4.325.

BERNARDO, H.; OLIVEIRA, F. (2018) Estimation of Energy Savings Potential in Higher Education Buildings Supported by Energy Performance Benchmarking: A Case Study. Environments, v. 5, p. 85.

BHATT, A. H.; TAO, L. (2020) Economic Perspectives of Biogas Production via Anaerobic Digestion. Bioengineering, v. 7, p. 74.

BURAK, P.; SIMANAVIČIENÉ, Ž. (2018) Methods of Prevention Risks to the Country's Economic Security. Visuomenès Saugumas Ir Viešoji Tvarka, v. 21, p. 15-25.

CHU, W.; CHAI, S.; CHEN, X.; DU, M. (2020). Does the Impact of Carbon Price Determinants Change with the Different Quantiles of Carbon Prices? Evidence from China ETS Pilots. Sustainability, v. 12, p. 55-81.

DADALKO, V. A.; ISAEV, N. V.; CHEKMAREV, V. V.; SOLOVKINA, E. D. (2017) Jeffektivnost' sistemy jekonomicheskoj bezopasnosti sub'ektov Rossijskoj Federacii. Vestnik VSGUTU, v. 1, n. 64, p. 85-95.

DAGILIŪTĖ, R. (2008) Analysis of Changes in Eco-efficiency of Production and Consumption in Lithuania during the 1990-2006 Year Period. Ph.D. thesis. Kaunas: Vytauto Didžiojo Universitetas.

EU STRATEGY FOR THE BALTIC SEA REGION. Available: <https://www.balticsearegion-strategy.eu/>. Access: 11 July 2020

EUROPEAN COMMISSION. Available: <https://ec.europa.eu/eurostat>. Access: 10 July 2020

FIGAJ, R.; ŻOŁĄDEK, M.; GORYL, W. (2020) Dynamic Simulation and Energy Economic Analysis of a Household Hybrid Ground-Solar-Wind System Using TRNSYS Software. Energies, v. 13, p. 3523.

FRANKI, V. V. (2015) Energy Security, Policy and Technology in South East Europe: Presenting and Applying an Energy Security Index to Croatia. Energy, v. 90, p. 494-507. DOI: https://doi.org/10.1016/j.energy.2015.07.087 
FERREIRA, D. H. L.; BARON, C.; FUJITA, H. (2016) An application of full cost assessment in the energy sector. Independent Journal of Management \& Production, v. 7, n. 3, p. 903-913. DOI: http://dx.doi.org/10.14807/ijmp.v7i3.438

GALINDO-RUEDA, F.; APPELT, S.; GONZÁLEZ-CABRAL, A. (2018) Indicators of R\&D Tax Support. Issues in Science and Technology, v. 34, n. 4, p. 85-88. DOI: $10.2307 / 26597994$

GIRIŪNIENĖ, G.; ČERNIUS, G.; GIRIŪNAS, L.; JAKUNSKIENE், E. (2019) Research on the Relation between Conceptions of the State's Economic and Financial Security:

Theoretical Aspect. Journal of Security and Sustainability Issues, v. 8, n. 4, p. 609-616.

STAMM, G.; MISSAGGIA, A.; SANTOS, B. M.; SILVEIRA, F.; RODRIGUES, P. C. C.; MOLINAR, F. (2019) Order of emergency orders in a company of distribution of electrical energy. Independent Journal of Management \& Production, v. 10, n. 4, p. 1250-1270. DOI: dx.doi.org/10.14807/ijmp.v10i4.968

HIPP, L. (2016) Insecure times? Workers’ Perceived Job and Labor Market Security in 23 OECD Countries. Social Science Research, v. 60, n. 2, p. 1-14. DOI:

https://doi.org/10.1016/j.ssresearch.2016.04.004

INTERNATIONAL ENERGY AGENCY. Available:

<http://www.iea.org/media/statistics/IEA_HeadlineEnergyData.xlsx>. Access: on 10 July 2020.

JOHNSTONE, C. P. (2013) A techno-Economic Analysis of Tidal Energy Technology.

Renewable Energy, v. 49, p. 101-106. Available:

<http://www.sciencedirect.com/science/article/pii/S0960148112000651>. Access: on 12 July 2020.

KREMER-MATYŠKEVIČ, I.; ČERNIUS, G. (2019) Country's economic security concept: Theoretical insights. Whither Our Economies - 2019: International Scientific Conference. Proceedings..., v. 6, p. 78-98.

KROMALCAS, S.; SIMANAVIČIENĖ, Ž.; BIČKAUSKĖ, D. (2019) Economic Security as a Phenomenon and Concept. Whither Our Economies - 2019: International Scientific Conference. Proceedings..., p. 64-77.

LAPINSKAITĖ, I.; SKVARCIANY, V.; JANULEVIČIUS, P. (2020) Impact of Investment Sources for Sustainability on a Country's Sustainable Development: Evidence from the EU. Sustainability: Special Issue "Sustainable Investment And Finance”, v. 12, n. 6, 2421, p. $1-23$.

MAČERINSKIENĖ, I.; KREMER-MATYŠKEVIČ, I. (2017) Assessment of Lithuanian energy sector influence on GDP. Montenegrin Journal of Economics, v. 13, n. 4, p. 43-59.

MANGULA, M. Sh.; KUZILWA, J. A.; MSANJILA, S. S.; LEGONDA, I. (2019) Energy sources for cooking and its determinants in rural areas of Tanzania. Independent Journal of Management \& Production, v. 10, n. 3, 934-950.

DOI: http://dx.doi.org/10.14807/ijmp.v10i3.796.

MASIP MACÍA, Y.; PEDRERA, J.; CASTRO, M.T.; VILALTA, G. (2019) Analysis of Energy Sustainability in Ore Slurry Pumping Transport Systems. Sustainability, n. 11, p. 3191.

MELTON, M.; HUDSON, A.; LADISLAW, S. (2015) Report. Center for Strategic and International Studies (CSIS). DOI:10.2307/resrep23569. 
DOI: 10.14807/ijmp.v11i9.1399

MENDOZA, E. G.; QUADRINI, V.; RIOS-RULL, J. V. (2019) Financial integration, financial development, and global imbalances. Journal of Political economy, v. 117, n. 3, p. 371-416.

MENEZES, F. M.; GÓES, M. F.; KALID, R. A.; TANIMOTO, A. H.; ANDRADE, J. C. (2017) Economic feasibility of an energy efficiency project for a steam distribution system in a chemical industry. Independent Journal of Management \& Production, v. 8, n. 4, p. 1381-1399. DOI: dx.doi.org/10.14807/ijmp.v8i4.672.

MINISTRY OF ENERGY OF THE REPUBLIC OF LITHUANIA. Available: $<$ https://enmin.lrv.lt/en/sectoral-policy/heating-sector/sector-overview-2>. Access: 10 July 2020.

MORKŪNAS, M.; VOLKOV, A.; BILAN, Y.; RAIŠIENĖ, A. G. (2018) The Role of Government in Forming Agricultural Policy: Economic Resilience Measuring Index Exploited. Administratie Si Management Public, p. 111-131.

POPESCU, M. F. (2014) Energy Security - a Part of the Economic Security. Managementul Intercultural, v. 31, p. 289-296. Available: <https:// ideas.repec.org/a/cmj/interc/y2014i31p289-296.html>. Access: 08 July 2020.

REHM, P.; JACOB S. H.; SCHLESINGER, M. (2012) Insecure alliances: Risk, inequality, and support for the welfare state. American Political Science Review, v. 106, n. 2, p. 386406.

SIMANAVIČIUS, A.; SUBONYTE, J.; SIMANAVIČIENE், Ž. (2019) Perception of Economic Security. Visuomenès Saugumas Ir Viešoji Tvarka: Mokslinių Straipsnių Rinkinys, n. 22, p. 158-171.

STANAWAY, J. D.; AFSHIN, A.; GAKIDOU, E.; LIM, S. S.; ABATE, D.; ABATE, K. H.; ABDELA, J. (2017) Global, regional, and national comparative risk assessment of 84 behavioural, environmental and occupational, and metabolic risks or clusters of risks for 195 countries and territories, 1990-2017: a systematic analysis for the Global Burden of Disease Study 2017. The Lancet, v. 392 (10159), p. 1923-1994.

SVETLAKOV, A.; GLOTINA, I. (2018) Impact of Information Space on Economic Security in the Region. Economy of region. Centre for Economic Security, Institute of Economics of Ural Branch of Russian Academy of Sciences, v. 1, n. 2, p. 474-484.

SVIDERSKE், T. (2015) Country risk assessment in economic security and sustainability context: Ph.D. thesis. Vilnius: Vilniaus Gedimino technikos universitetas.

TAMOŠIŪNIENĖ, R.; MUNTEANU, C. (2015) Current research approaches to economic security. 1st International Conference on Business Management Universitat Politècnica de València. DOI: http://dx.doi.org/10.4995/ICBM.2015.1537.

U.S. ENERGY INFORMATION ADMINISTRATION. Available: <https://www.eia.gov/>. Access: 11 July 2020.

VINE, E. (2005) An international survey of energy service company (ESCO) industry. Energy Policy, n. 33, p. 691-704.

ZAVADSKAS, E. K.; ANTUCHEVIČIENĖ, J.; VILUTIENĖ, T.; ADELI, H. (2018) Sustainable Decision-making in Civil Engineering, Construction and Building Technology.

Sustainability, v. 10, n. 1, p. 1-21. 
ISSN: 2236-269X

DOI: 10.14807/ijmp.v11i9.1399

ZUZEVIČIŪTĖ, V.; ŠLAPKAUSKAS. V; SIMANAVIČIENĖ, Ž.; SIMANAVIČIUS, A.; VASILIAUSKIENĖ, V; PAURIENĖ, G.; VIDUOLIENE், E. (2018) Visuomenès saugumas ir darni plètra: visuomenès saugumo aktualijos ir probleminiai klausimai :

monografija, II issue. Kaunas: Mykolo Romerio universitetas. 